\title{
التاريخيّة: المفهوم وتوظيفاته الحداثية
}

\section{مرزوق العمري"}

\author{
الملخص \\ من المصطلحات التي أنتجتها الفلسفة الحديثة مصطلح "التاريخية"، الذي كانت بداية ظهوره في فاية القـــــن

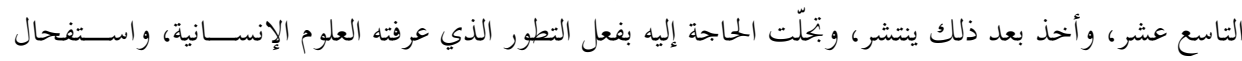

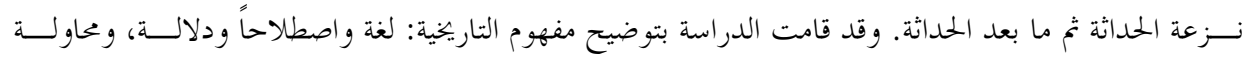

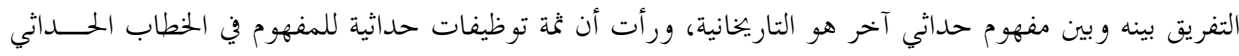

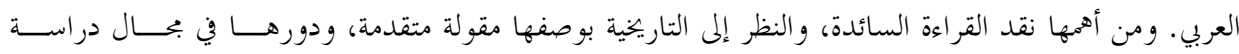

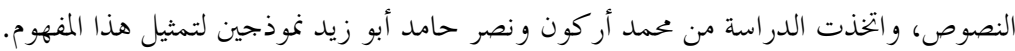 \\ الكلمات المفتاحية: التاريخية، القراءة الحداثية، النص الديني، التأويل.
}

\begin{abstract}
Modern philosophy has produced certain terms, one of these terms is "historicism" which has emerged by the end of the $19^{\text {th }}$ century, and spread widely through the development of human sciences and the spread of modernity and post modernity. This paper explained the concept and compared it with another one, namely "historicity." The paper found out that historicism has modern applications in modern Arab discourse such as the criticism of prevalent reading, and the study of text. The focus of the study is the writings of Muhammad Arcon and Nasr Hamid Abuzaid.
\end{abstract}

Keywords: historicity, historicism, religious text, hermeneutics.

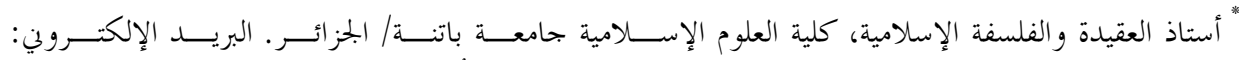
merlamri@yahoo.fr 


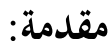

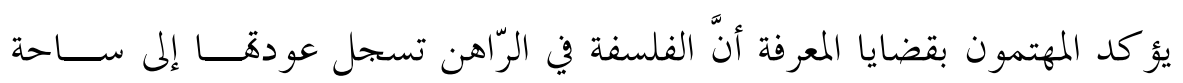

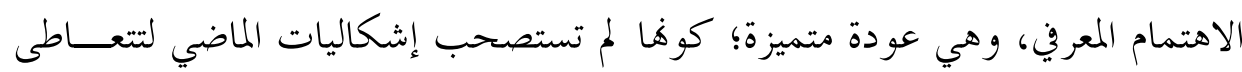
معها في الحاضر، بل راحت تستشكل من جديد بكل ما يتصل بالر اهن المعرفي. إنّ ما أفرزته الفلسفة الآن هو طبيعة النظر إلى قيمتها -الفلسفة- وحيويتها، الــتي

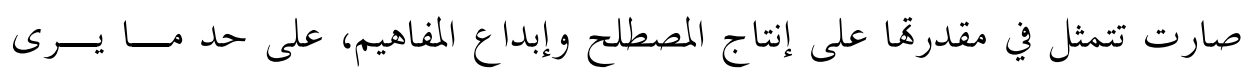
الفيلسوف الفرنسي جيل دولوز (Gilles Deleuze)

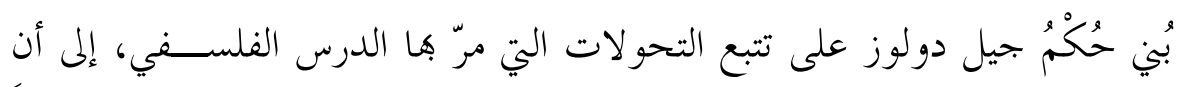

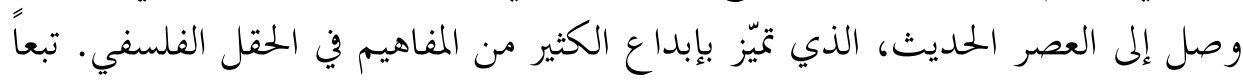

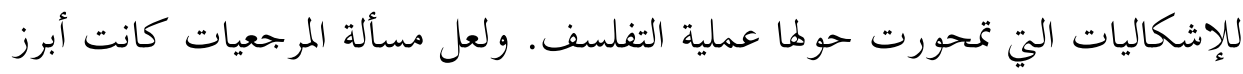

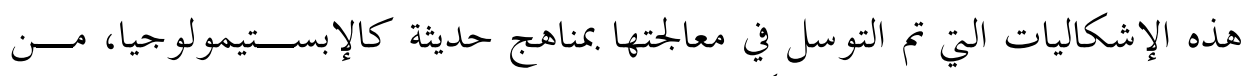

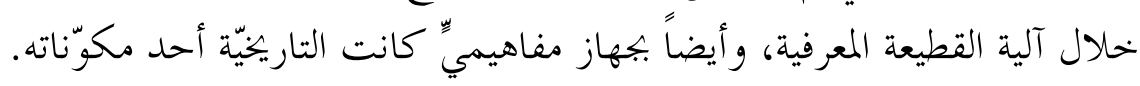
و التاريخية مفهوم تبلور في الفلسفة الغربية الحديثة، وهو يفضي إلى أن كل شـيء

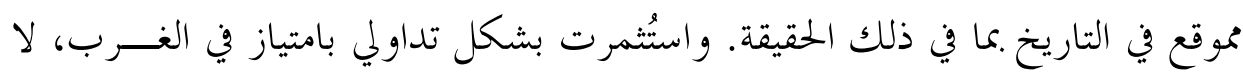

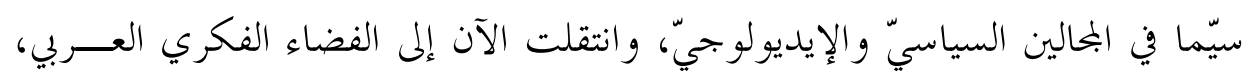

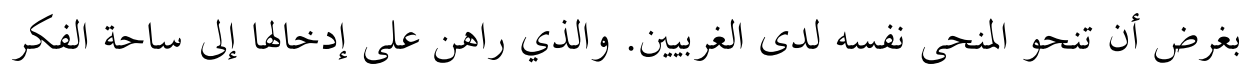

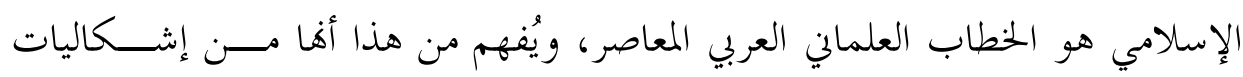
الفكر العربي الجديدة.

من هنا تشكَّل الباعث على البحث في هذا الموضوع، الذي يتمثل فيما يأتي:

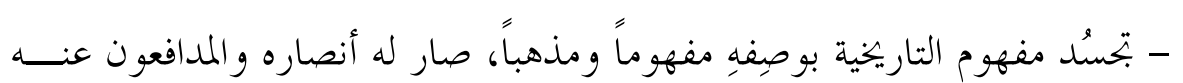
في الغرب، وفي الإطار الفكري العربي، بل بدأت تصدر كتابات تتحدث عن التاريخية

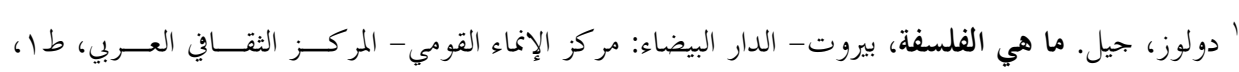

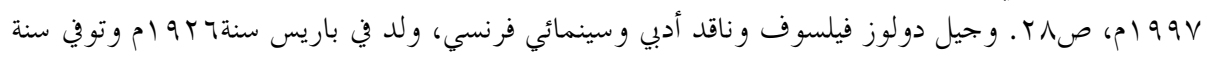

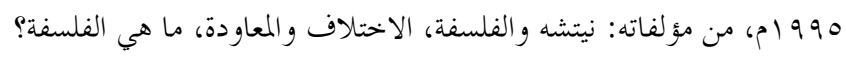


مثل: تاريخية الفكر العربي الإسلامي لمحمد أركون، وتاريخية الدعوة الخمديـــة لهشــام جعيط.

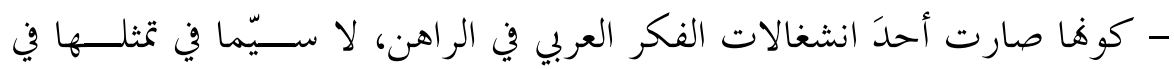

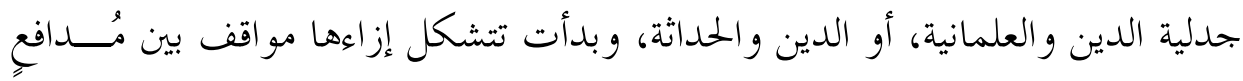
عنها ور افضٍ لها.

- المراهنة على إدخالها إلى ساحة الفكر الإسلامي، ويُنظكَر إليها على أهـــــا الآليــة

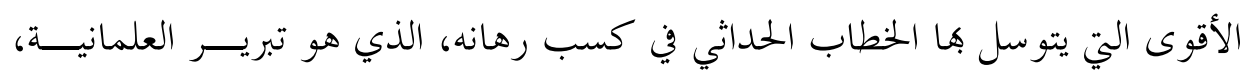

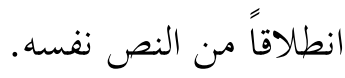

- التباس مفهومها في البحالات التي توظّف فيها، وعدم وضوحها إلى الدرجة التي

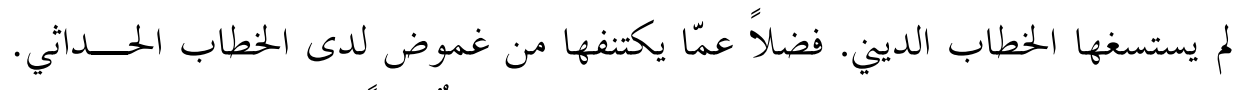
ولذلك يمكن القول: إن الكتابة في هذا الموضوع شحيحةٌ جدئاً.

بناء على هذه المسوّغات انتظمت إشكالية هذه الدراسة، التي تسعى إلى متابعــة

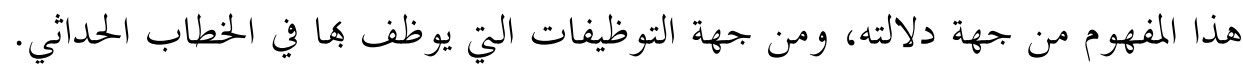

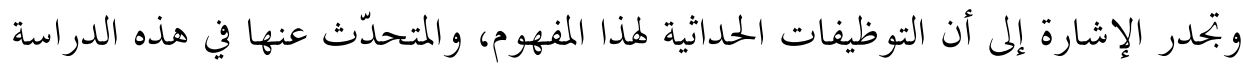

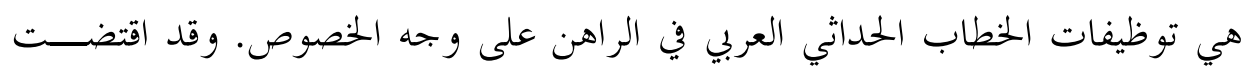

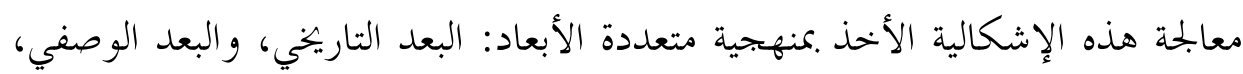

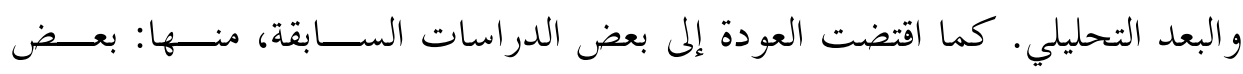

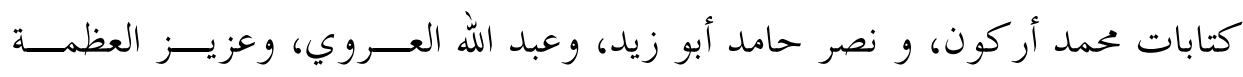
وغيرهم.

أولاً: دلالة التاريخية

1. التاريخية في اللغة: لم تحظ كلمة "التاريخية" بتعريفات لغوية عربيــة، شــأن

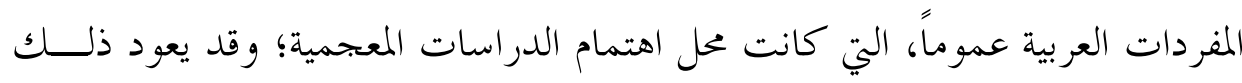

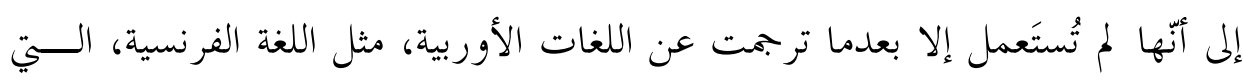


كانت تستعمل كلمة "Historicisme". فإذا تتبعنا المصطلح في اللغة العربية، سنجد

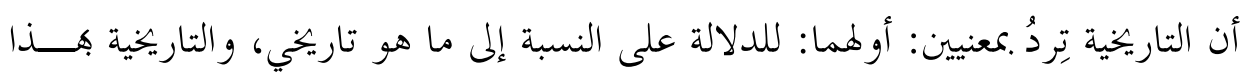

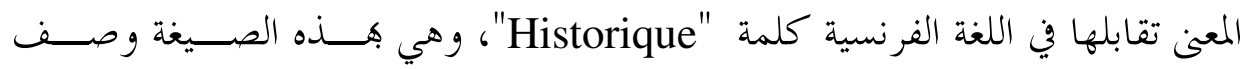

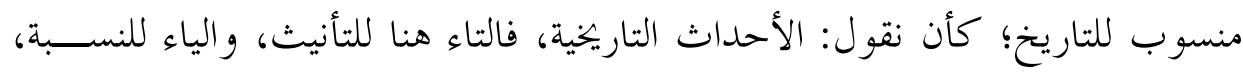

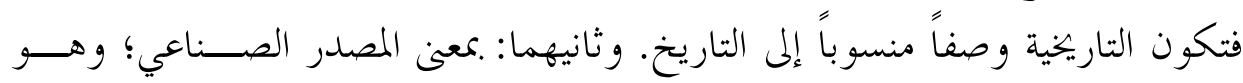

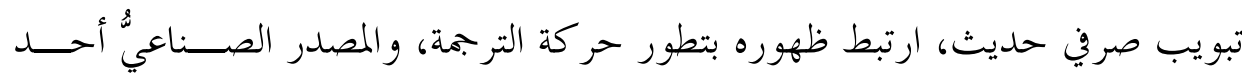

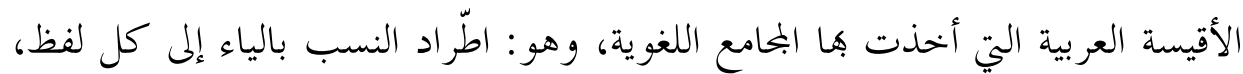

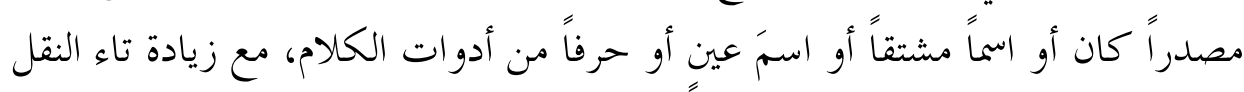

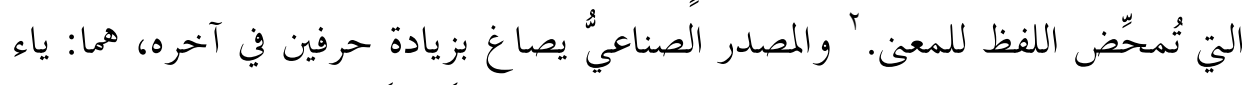

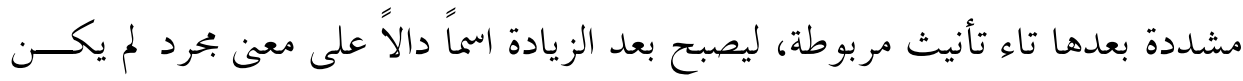

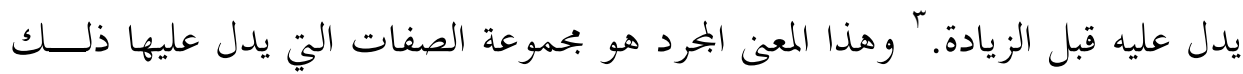

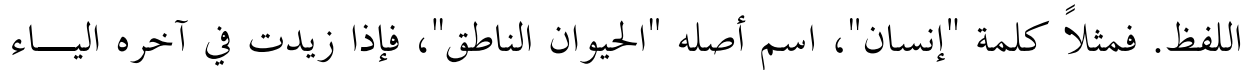

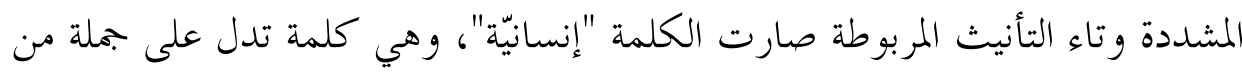
المعاني مثل: الرحمة، و الشفقة، و التعاون......

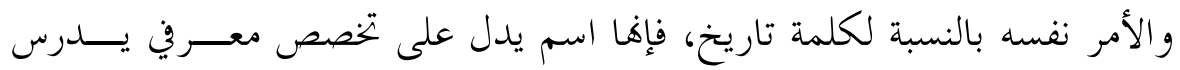

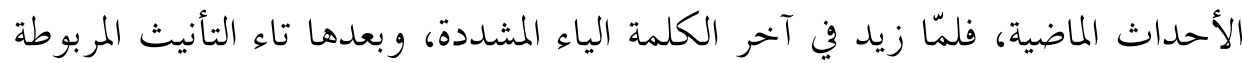

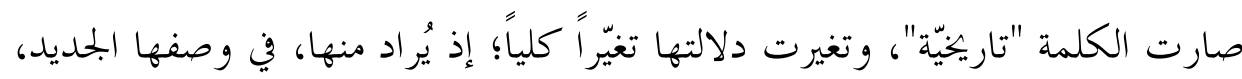

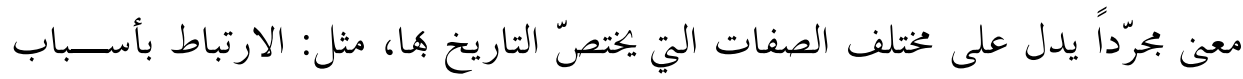

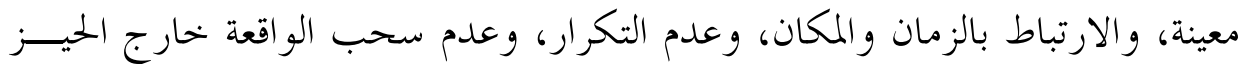

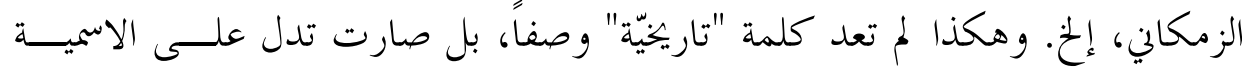

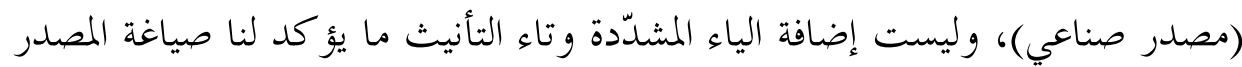

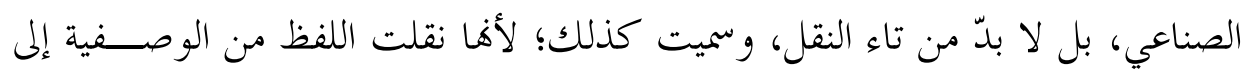

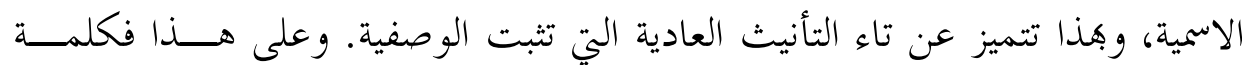

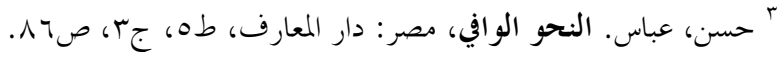


"التاريخيّة" في قولنا: الأحداث التاريخيّة تعني مظهراً من الإبناز ات التي تمت في الماضي،

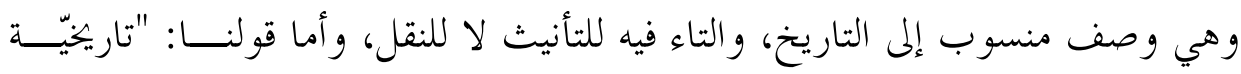

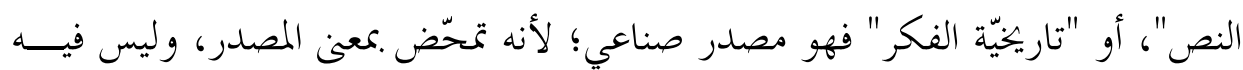
وصف شيء، بل التاء فيه نقلت اللفظ من الوصفية إلى الاسمية.

و وي الاستعمالات المعاصرة ترد كلمة "تاريخيّة" بالمعاني الــتي تضــمنتها اللغـــات الأوروبية. وحتى في هذه اللغات هي مصطلح حديث، فأول توظيف لمصطلح التاريخيّة

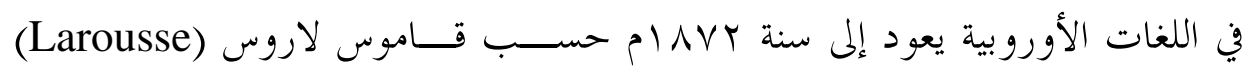

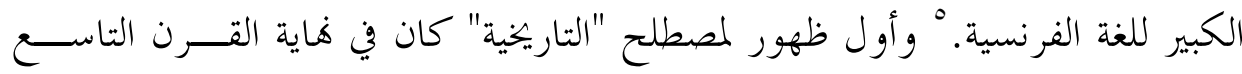

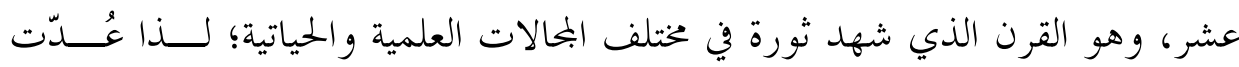

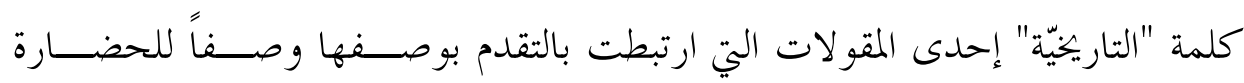

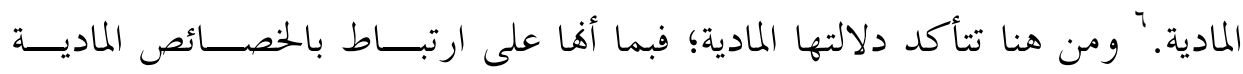

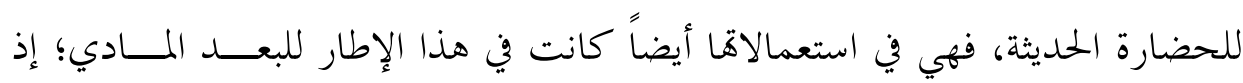

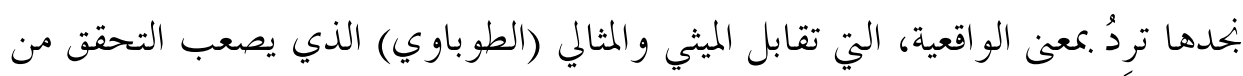

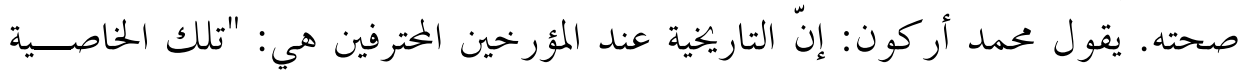

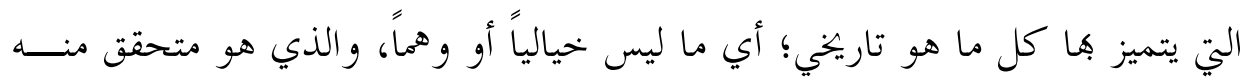
V". كمساعدة أدوات النقد التاريخي.

وإذا كانت التاريخية تحمل معنى الواقعية والتحقق العيني، فإها تُرد -ـأيضاً للدلالة

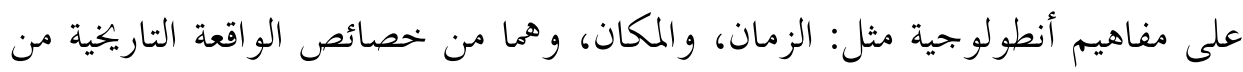

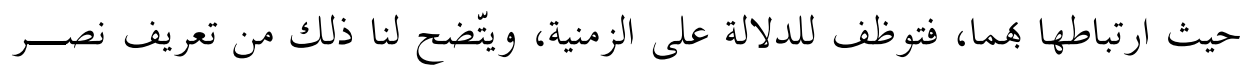

" اللبدي، محمد سمير بنيب. معجم المصطلحات النحوية والصرفية، بيروت: مؤسسة الرســالة، طب، 71919 (م)،

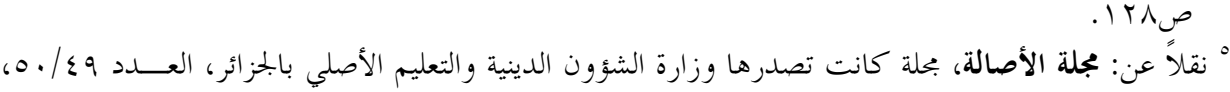

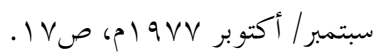
"أركون، محمد. الفكر الإسلامي قراءة علمية، بيروت- الدار البيضاء: المركز الثقافي العـربي، طب، 1997 (م) 


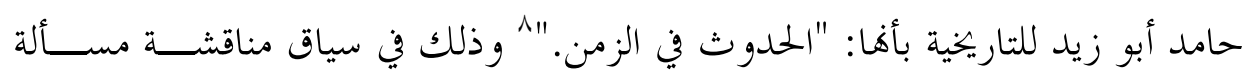

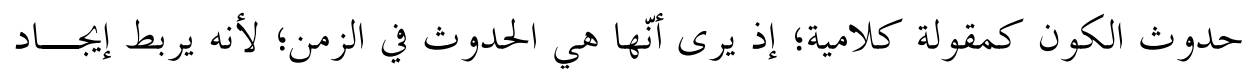

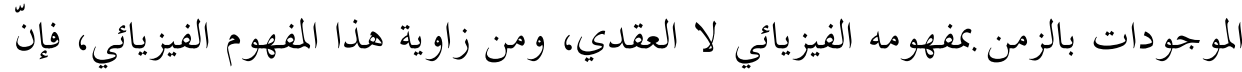

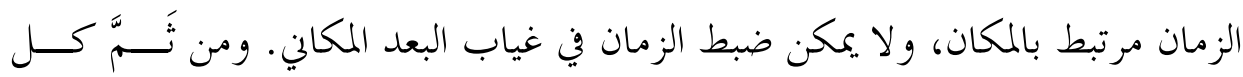
الأحداث وقعت بعد خلق الكون بما في ذلك الكام الإلهي؛ ولذلك قال بتاريخيته؛ أي ولي

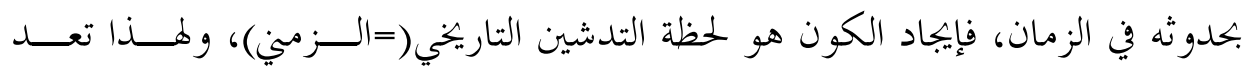

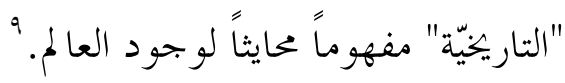

و "التاريخّيّة" هذا المعنى تصبح آلية من الآليات التي يميّز هـا بين الغـيـي والـــواقعي،

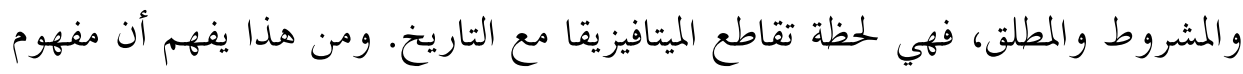

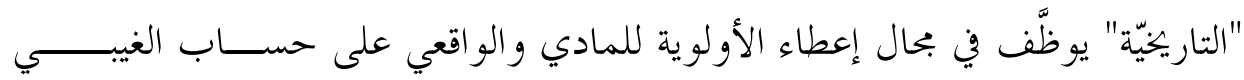

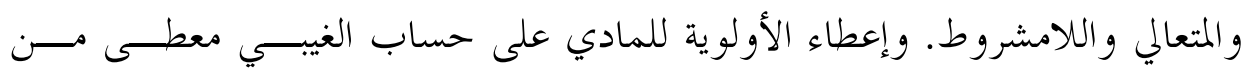
معطيات الفلسفة الوضعية التي استفحلت في القرن التاسع عشر مع الفيلسوف الفرنسي أوجيست كونت.

من جهة أخرى بخد "التاريخيّة" تتميز عن مصطلح حداثي آخر، هو "التاريخانية".

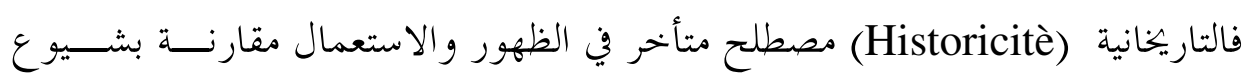

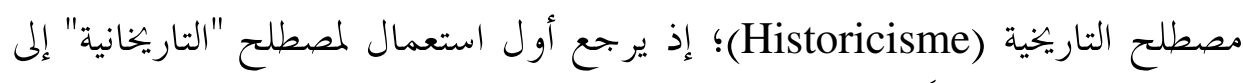

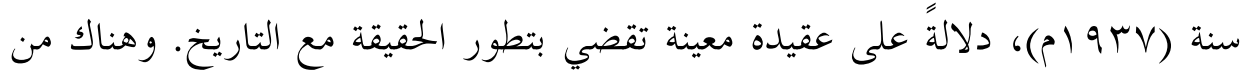

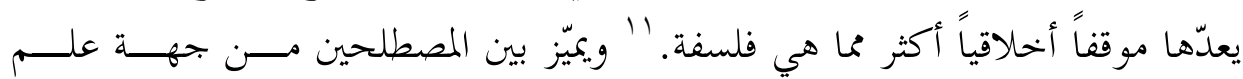
اللسانيات بالوقوف عند لاحقة "الألف و النون" التي تضمنتها كلمة "تاريخانية"، وهذه وهنه اللازمة التي تميل إلى صفة واقع جوهري.

^ أبو زيد، نصر حامد. النص السلطة والحقيقة، بيروت- الدار البيضاء: المركز الثقافي العـربي، طء، .... Fم،

" المرجع السابق، الصفحة نفسها.

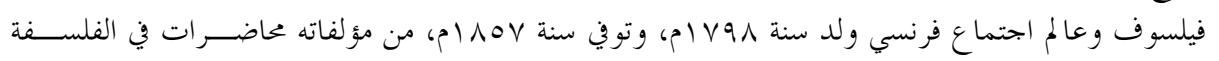

"' العروي، عبد الله. ثقافتنا في ضوء التاريخ، بيروت- الدار البيضاء: المركز الثقافي العربي، لو9 ام، صه 1. 
وعلى أساس وجهة النظر اللسانية هذه، يميّز أركون بين المصطلحين، فــيرى أنّ

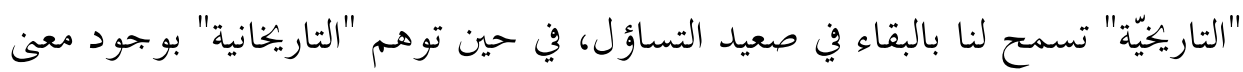

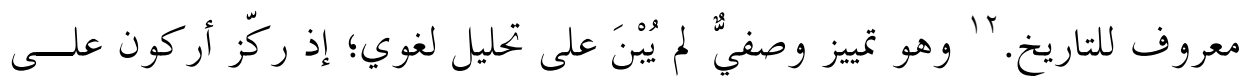

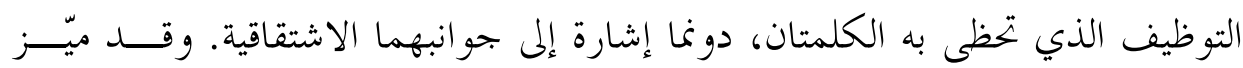
معجم أكسفورد بينهما على النحو الآتي: "التاريخيّة" (Historicism): الرأي القائل بإن الحتمية التاريخية وأحداث التـــاريخ

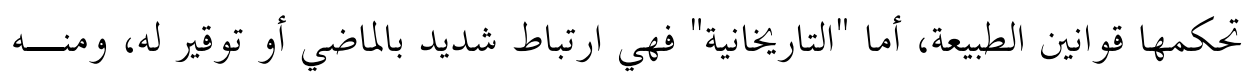

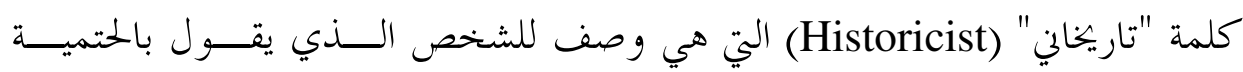

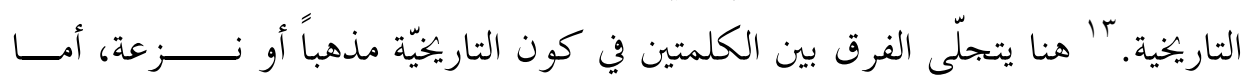
"التاريخانية" فهي صفة، وهذا ما أشار إليه معجم روبير (Le petit robert) الذي بند

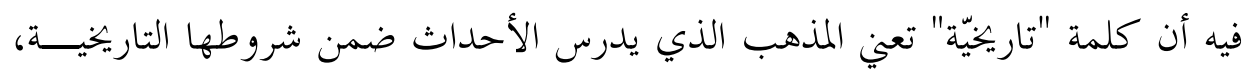

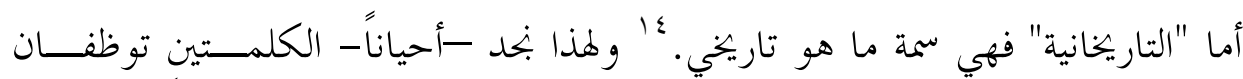

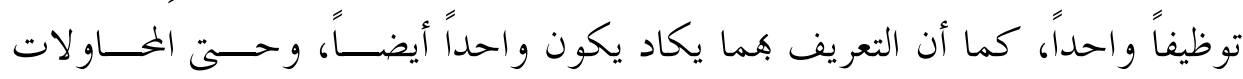

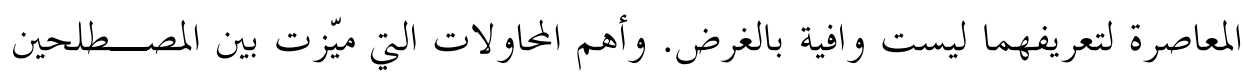
تستفاد من كتابات محمد أركون، فله إشارات في هذا، منها:

- التاريخانية مفهوم يثير مناقشات لا هاية لها، إلى حد صسعوبة اسـتعماله؛ لأن معظم التعريفات إيديولوجية، في حين التاريخيّة غير ذلك. - التاريخانية تقر .كسلَّمات فلسفية أو إيديولوجية، أما التاريخيّة فتسمحُ لنا بالبقاء في صعيد التساؤل.

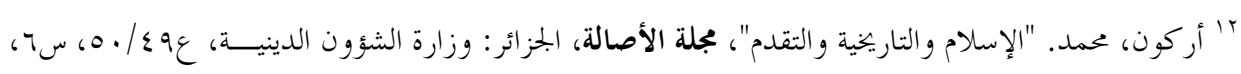

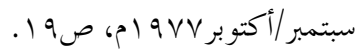

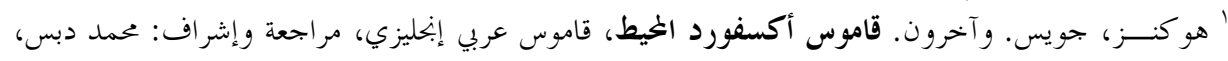
بيروت: أكاديما، د.ت. ${ }^{14}$ Le petit Robert de la Langue Française, nouvelle Edition (1992), p932. 


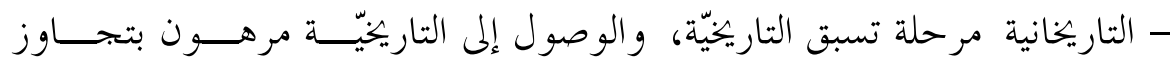

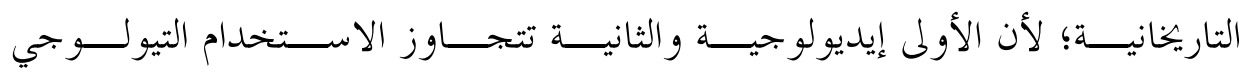
والإيديولوجي.

r. التاريخيّة في الاصطلاح: أما التاريخية في الاصطلاح فقد عُرّفــت تعريفــات متعددة، منها: - مان

- تعريف توران (Alaine Tourine) الذي عرفها بأها: "مقدرة كل بحتمع على

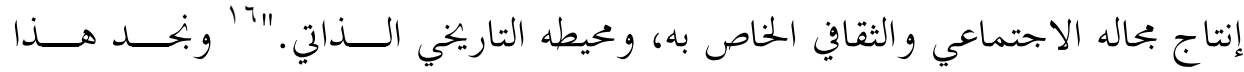

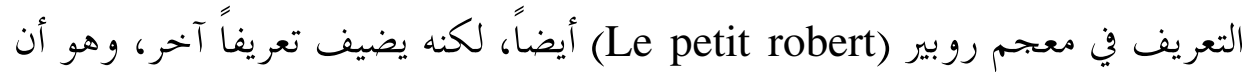

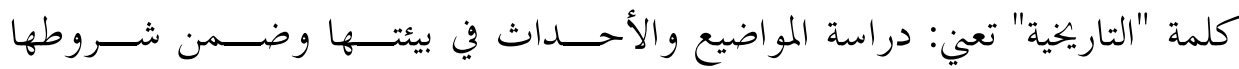

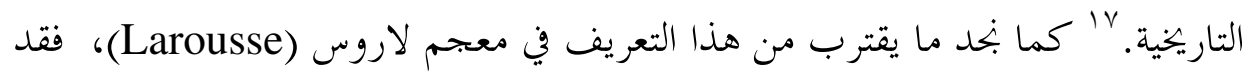

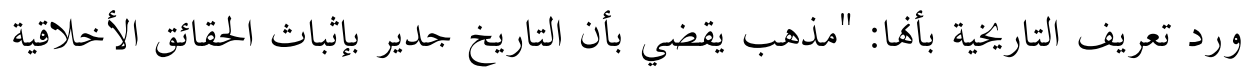

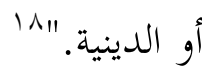

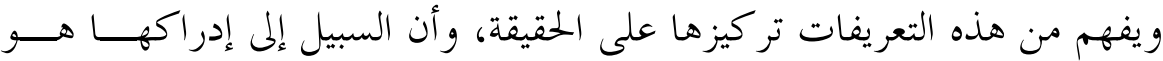

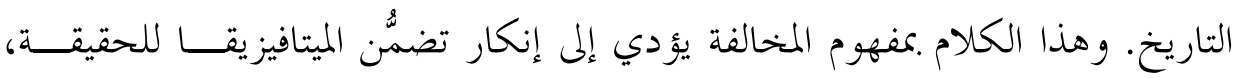

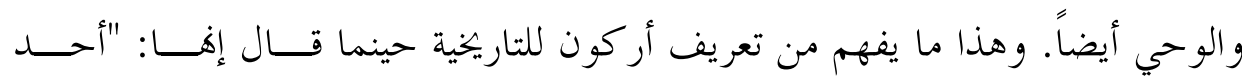

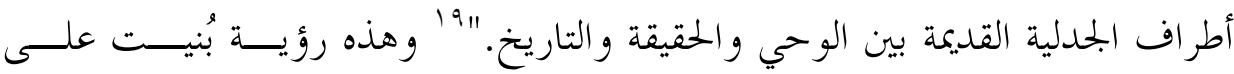

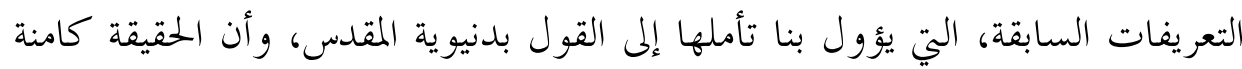

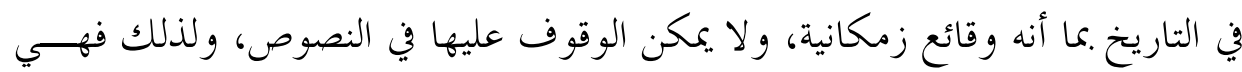
أحد أطراف الجدلية مع الوحي حول الحقيقة.

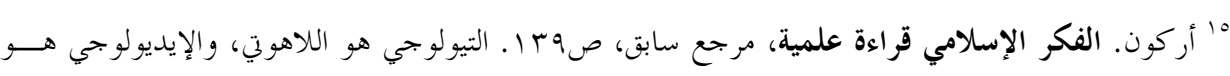

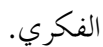

${ }^{17}$ Le petit Robert, p932. 1" أركون. الإسلام والتاريخية والتقدم، مرجع سابق، صم1.

${ }^{18}$ Le petit Larousse, Librrairie Larousse (1990), p493.

19 أركون. الإسلام والتاريخية والتقدم، مرجع سابق، ص103. 
وقد التمس الخطاب الحداثي تسوّيغاً لهذا التوظيف؛ إذ يرى أن الفكر الإســلامي

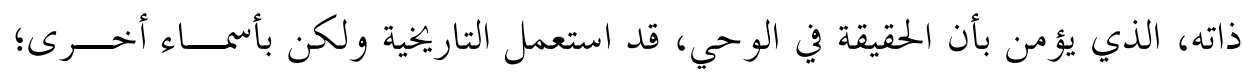

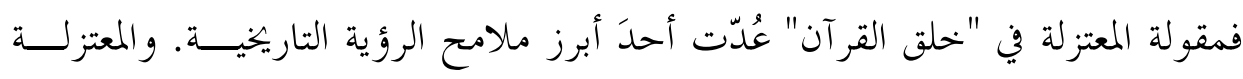

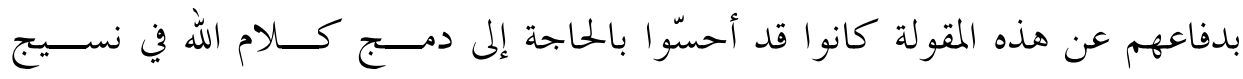

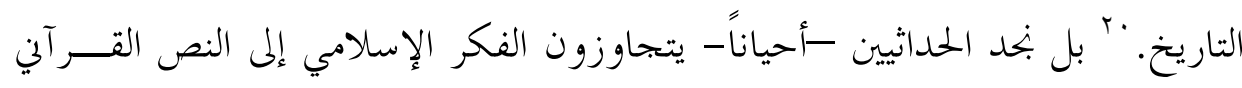
نفسه، يقول محمد أركون: "بخد من خلال القصص القرآني أن وعياً تاريخياً بدئياً يميل

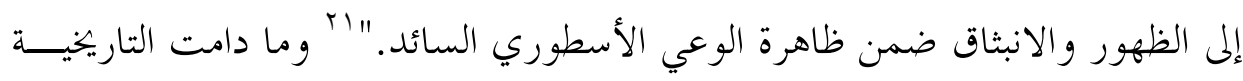

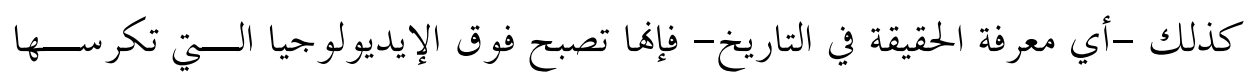

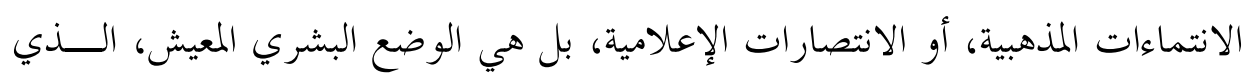
يمكنّا من بتحاوز التاريخ الإيديولوجي إلى التاريخ التطهيري.

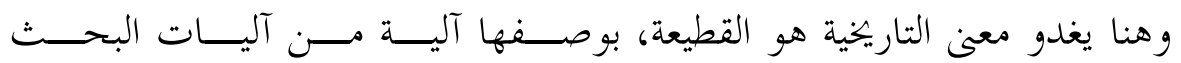

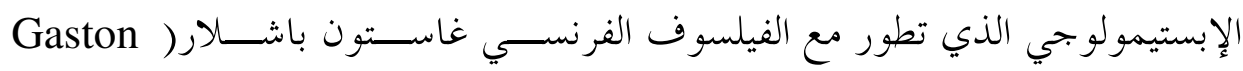
Bachelard

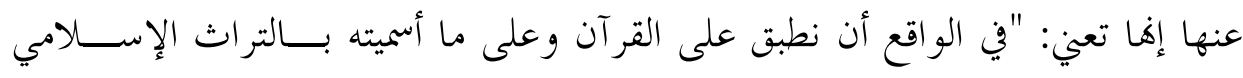

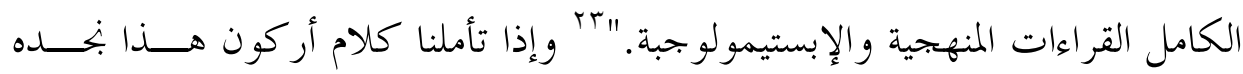
ينطوي على تناقض؛ وذلك لسببين:

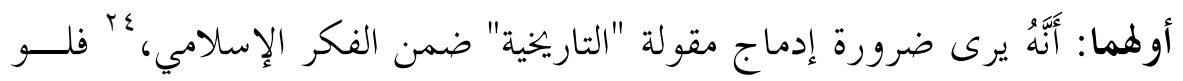

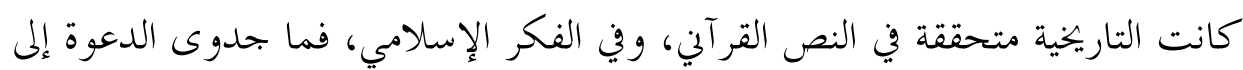

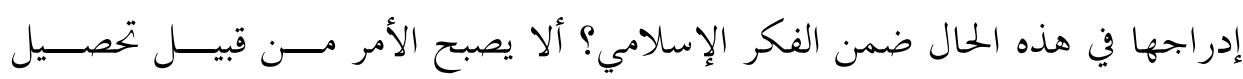

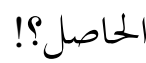

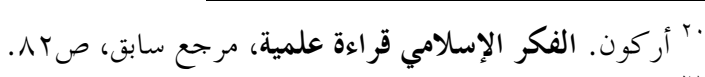

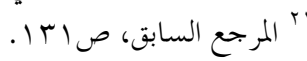

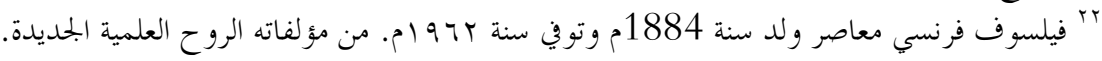

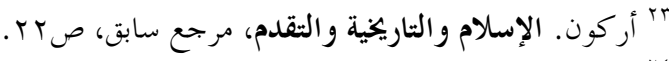

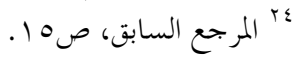


وثانيهما: في دراسة حممد أركون للخطاب القرآني، يرى أن هذا الخطاب عنـــدما

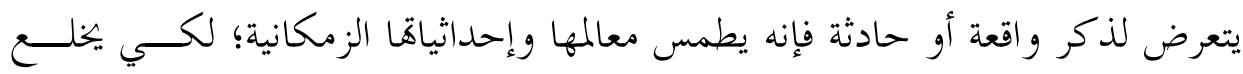

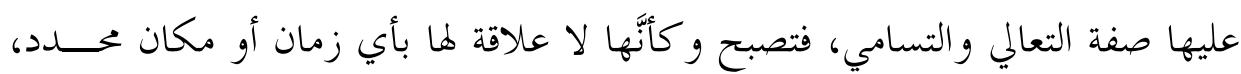
فتصبح شيئاً رمزياً يتجاوز التاريخ ويعلو عليه.

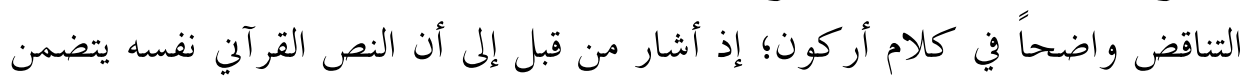

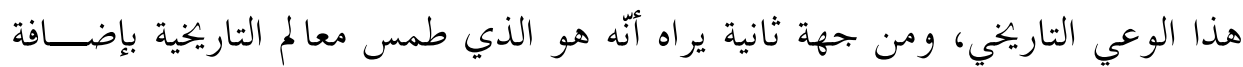
التقديس وخحلعه على الو اقع.

كما بحد أنّ التاريخية عرّفت بما يوحي باستمرار هذه الجحلية بينها وبين الــوحي

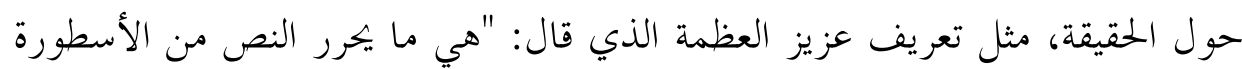

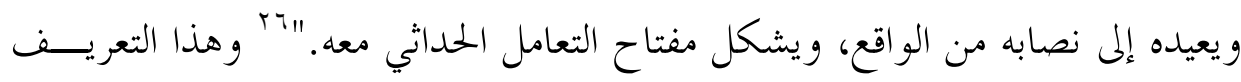

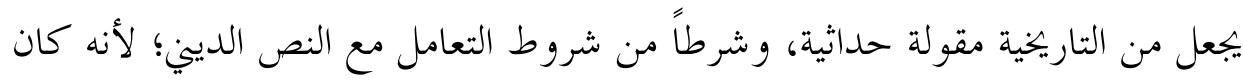

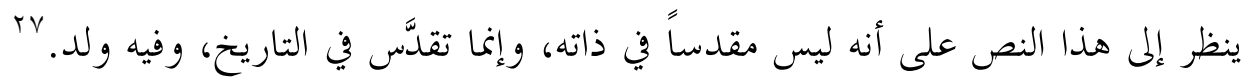

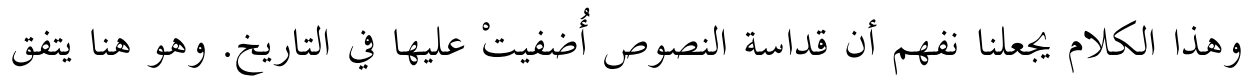

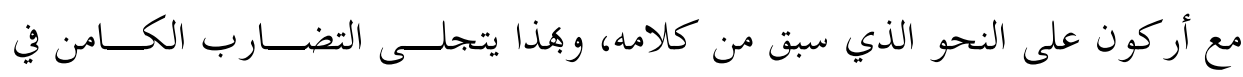

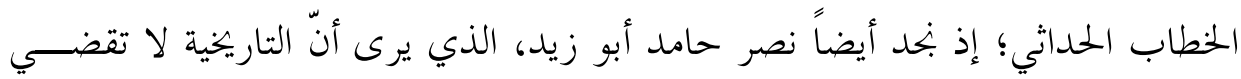

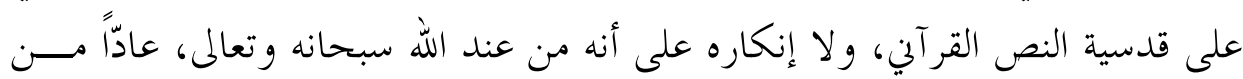
يقول بذلك جاهلاً.

و التاريخية حسب هذه التعريفات ذات دلالة أنثروبولوجية وضعية، تقضي بضرورة

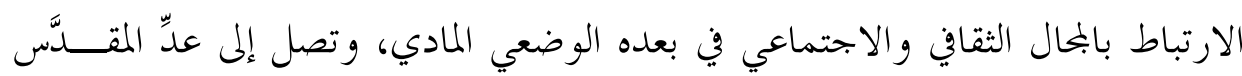

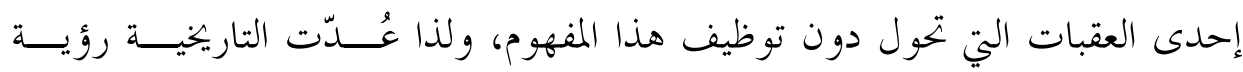

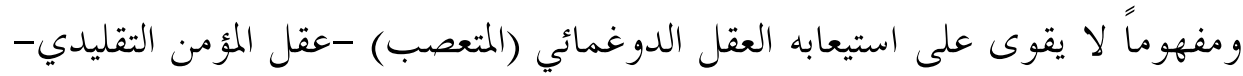

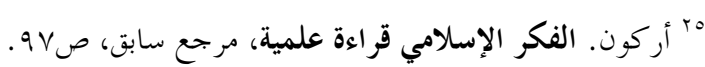

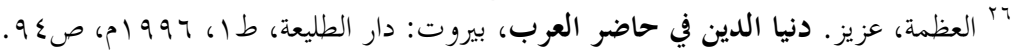

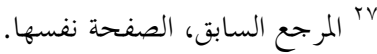

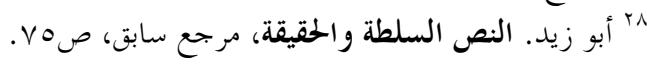




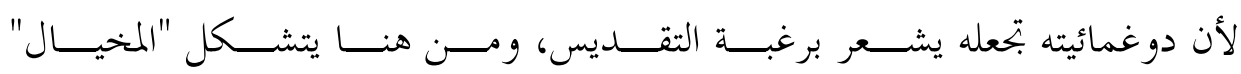
(L’imaginaire)

من جهة أخرى بحد تعريفات ذات دلالة أنطولوجية؛ أي أفا على اتصال .مبحث الوجود .معناه الفلسفي، من خلال التركيز على بعدي الزمان والمكان، لا سيّما عنصر

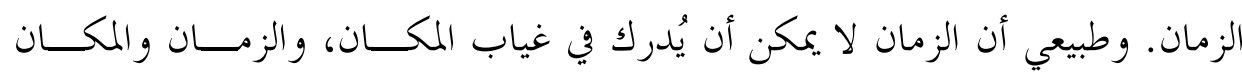
مباحث وجودية، وقد استعان نصر حامد أبو زيد في هذا بمباحث الوجود كما قررها

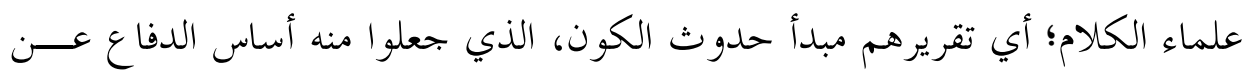

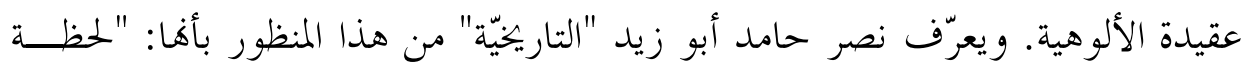

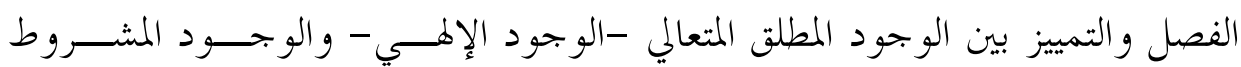

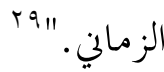

و يلاحظ على هذا التعريف أنّه وقف عند الوجود في مستو ييه: الإلهي والكـــوني،

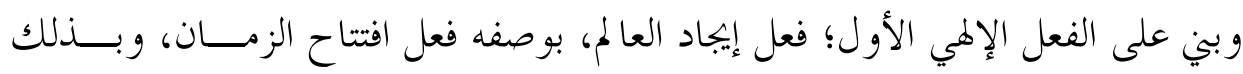
فكل الأفعال التي كانت بعده، بما في ذلك النص القرآي، تظل أفعالاً تاريخية، بحكم أهنا

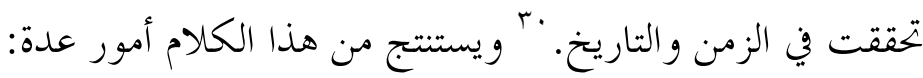

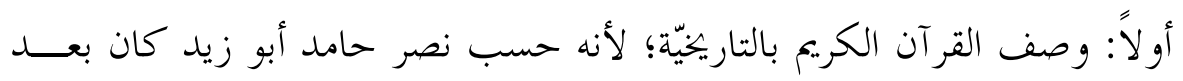

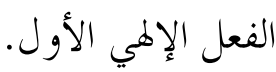
ثانياً:وصف السنة النبوية -أيضاً- بالتاريخية، بوصفها نصاً بتحلـى في الــزمن وفي

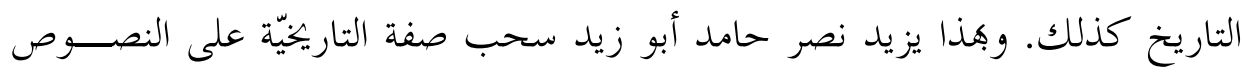

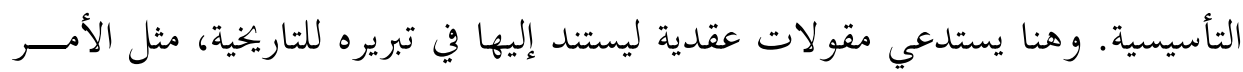

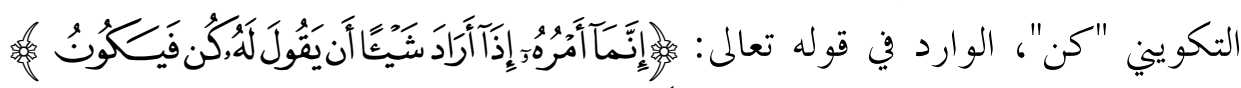

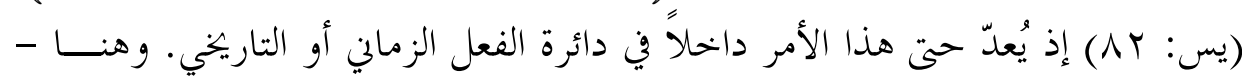
أيضاً - نجد مغالطات، منها:

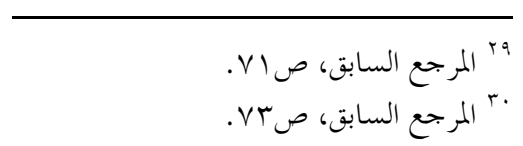




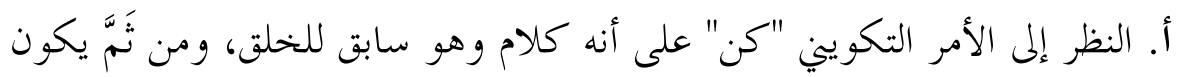

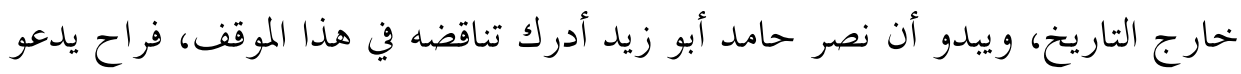

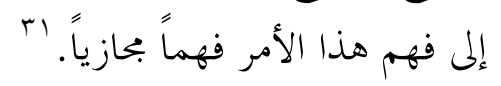

ب. بحسب قول نصر حامد أبو زيد، تصبح جميع الصفات الإلهية صفات أفعال، ولا توجد صفات ذات، و كأنه يرفض التمييز بين الصفة ومقتضاها، بل يخالف جمهور

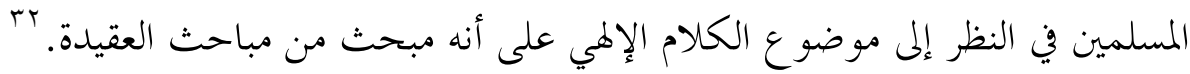

ثانياً: التوظيفات الحداثية للمفهوم

يوظف مصطلح "التاريخيّة" في الخطاب الحماثي العربي المعاصر في بحالات عســدة، منها:

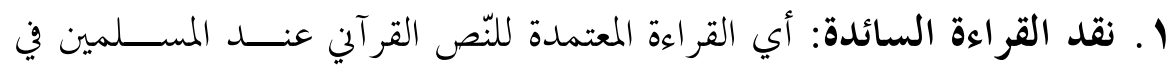

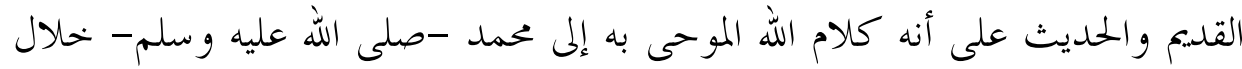

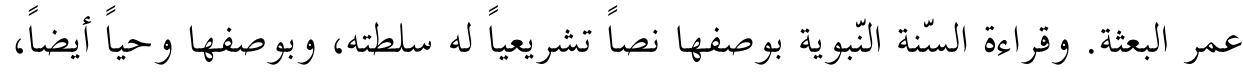

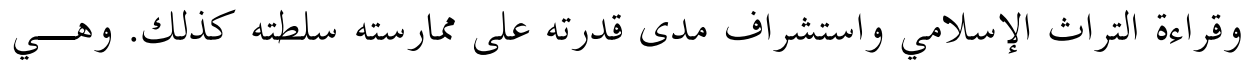

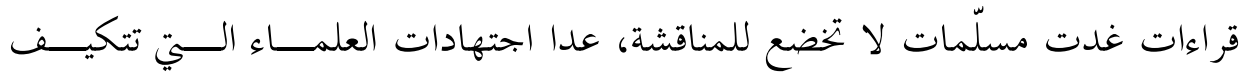

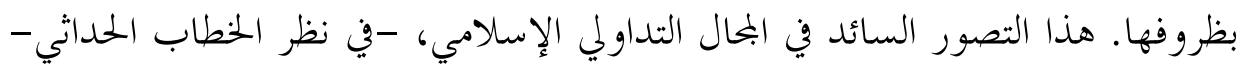

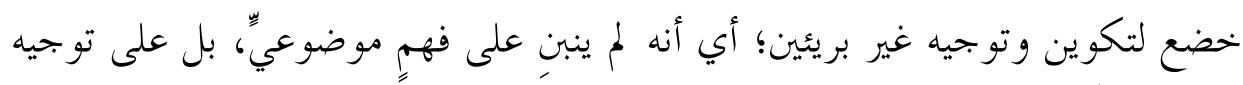

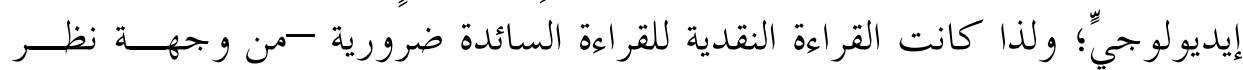
التاريخية- للكشف عن هذا البعد الإيديولوجي الكامن في القراءة السائدة منذ اللحظة

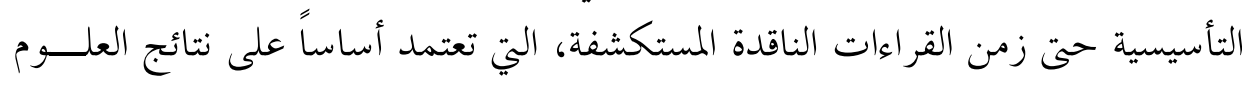
الإنسانية ومناهجها المتعددة.

وهذا التوجيه الإيديولوجي مبينّ على نظرة خحاصة لطبيعة تلك القــــراءات، الــتي كرّست و حدة إسلامية صلبة، وقفت في وجه الشبهات المثارة، و كلها لم تفلح في نشر 
نــزعة التشكيك أو زعزعة القناعات، أو التفكير في اللامفكُّ فيه بتعبير محمد أركون، الذي يعترف بعجز النقد المعاصر عن اقتحام القراءة السائدة، فيقول: "بحد أنفسنا اليوم عاجزين أكثر من أي وقت مضى عن فتح الإضبارات التي أُغلقت منذ القرنين الثالث

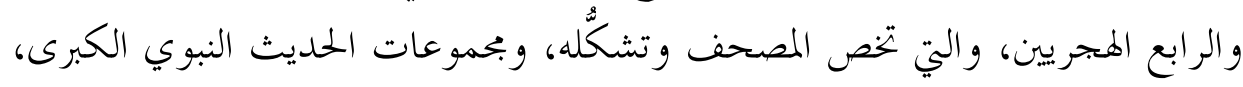

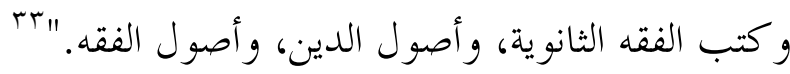

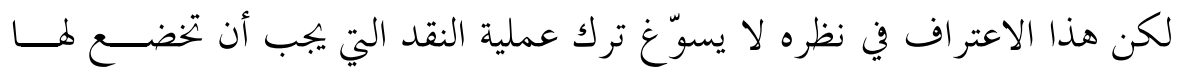

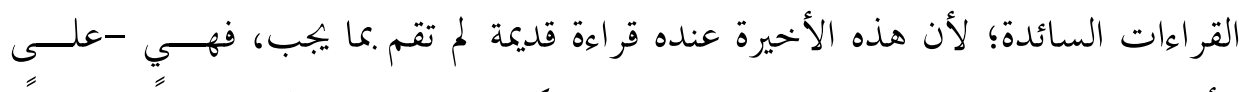
الأقل - امتصت الزمن الوضعي للتاريخ الذي يشكل في الزمن القرآي عنصراً حاسيــاً،

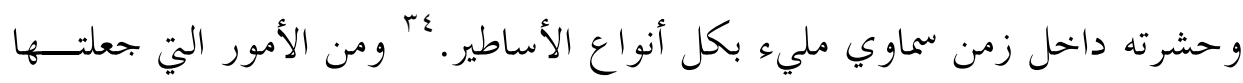
تؤول إلى هذا المآل : أ. قرارات الحكام؛ أي القرارات التي اتخذها الخلفاء بخصوص تدو ين النصـــوص، مثل قرار عثمان بن عفان -رضي الله عنه- بتدوين المصحف الشريف، وقرار عمر بن

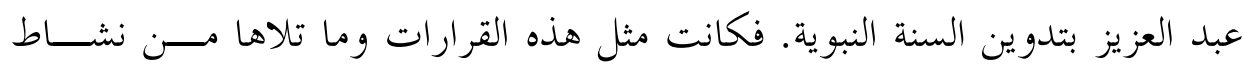

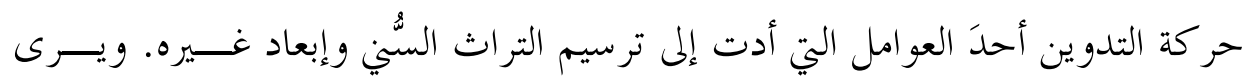

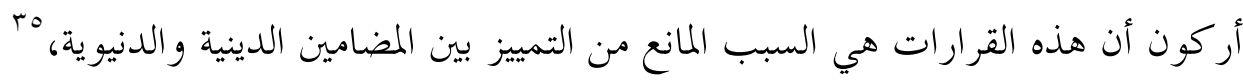

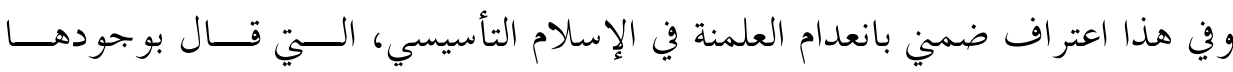
أركون في مواضع أخرى.

ب. دوغمائية العقل المتلقي: هذه الدوغمائية التي تتمثل في اليقينيات الرّاســـة

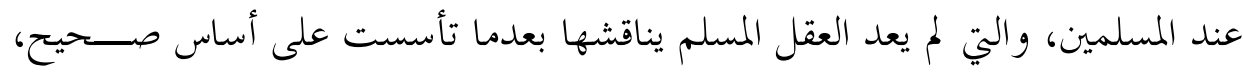

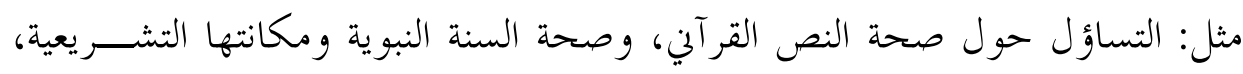
وصحة اجتهادات علماء المسلمين ما لم يتوفر مرجح يجعل منها اجتهادات مرجوحة.

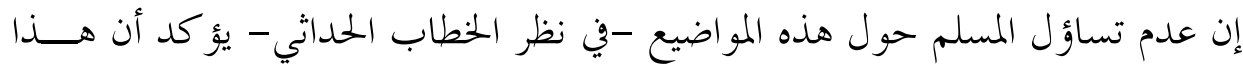

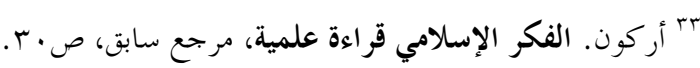

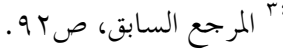

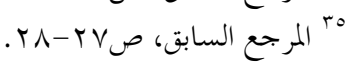




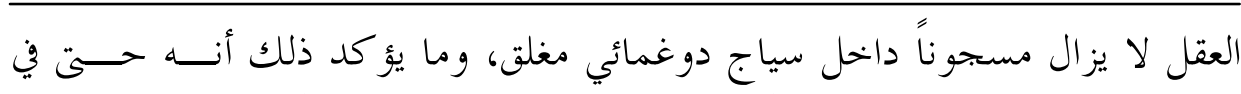

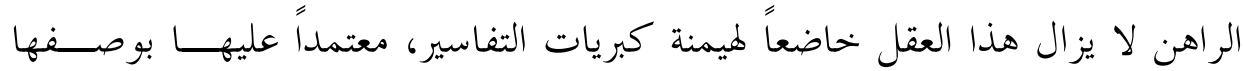
مرجعيات لا يمكن تبحاوزها.

وهذه القراءة في منظور الخطاب الحداثي مرفوضة؛ لطبيعتها الدوغمائية هذه الــتي

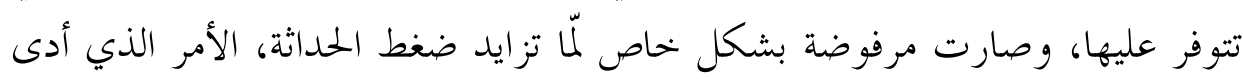

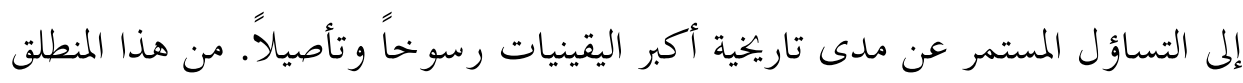

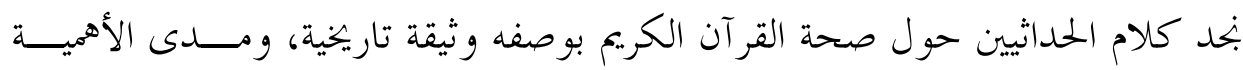

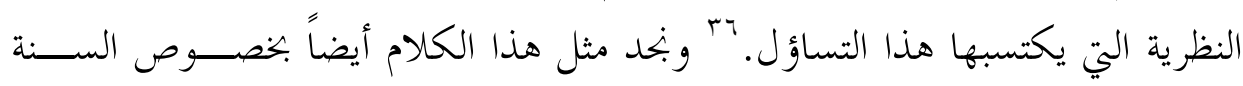

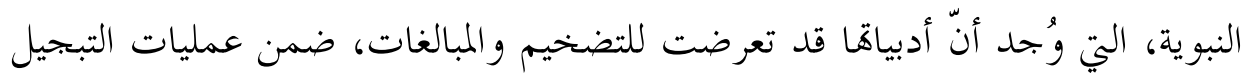
و التقديس التي خضعت لها تاريخياً.

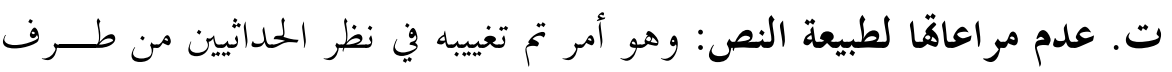

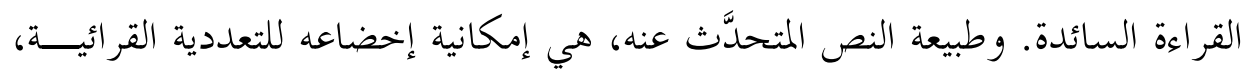

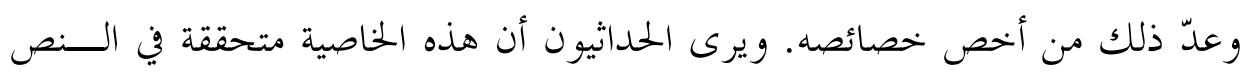

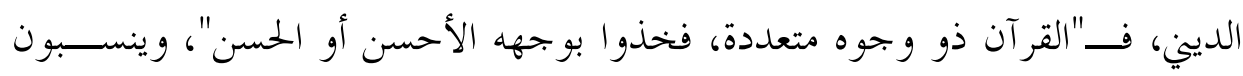

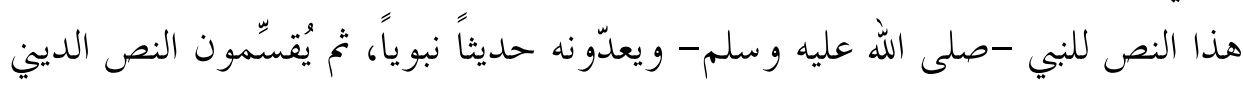

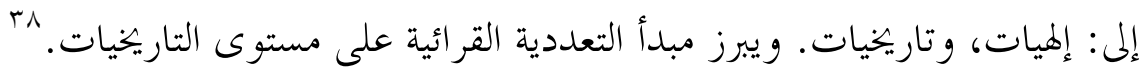

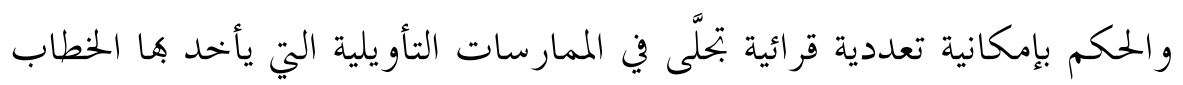

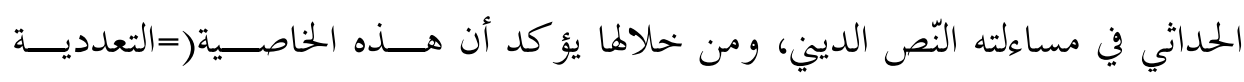

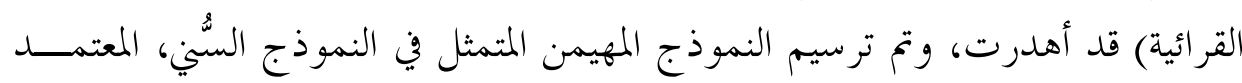

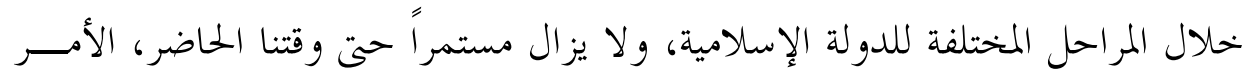

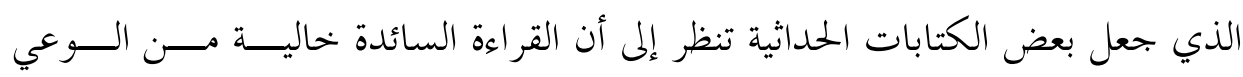

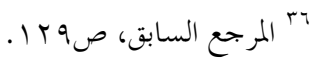

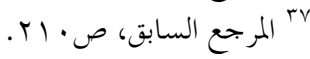

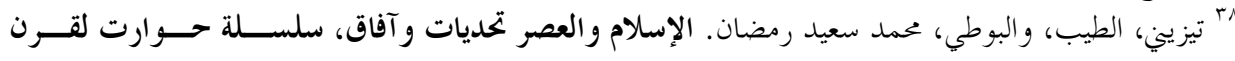




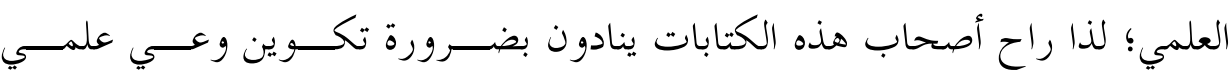
بالتراث.

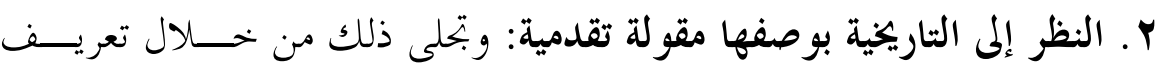

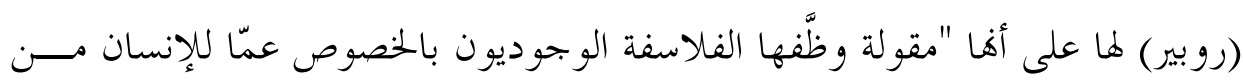

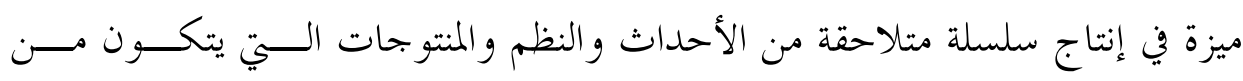

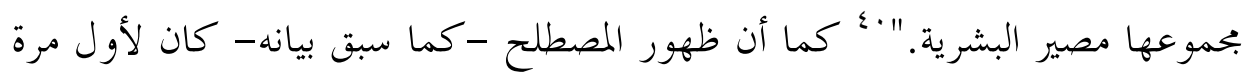

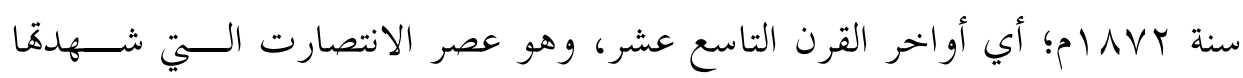

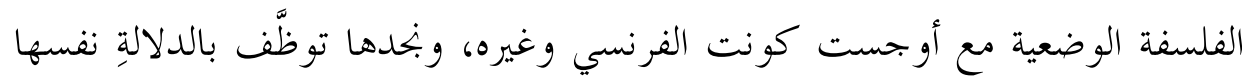

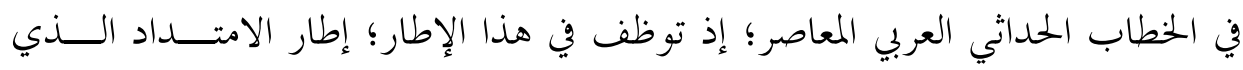

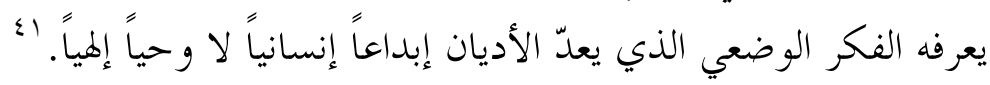

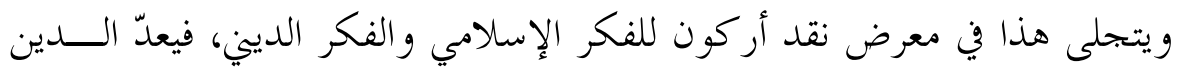

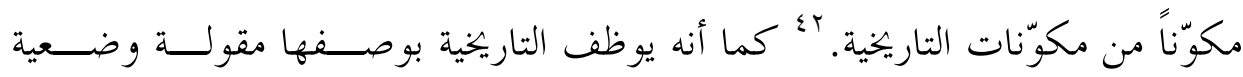

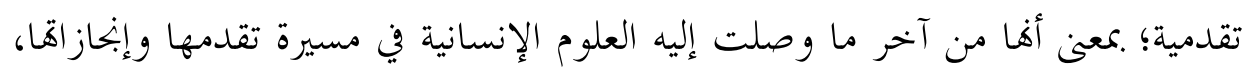

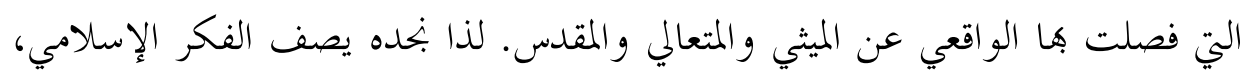

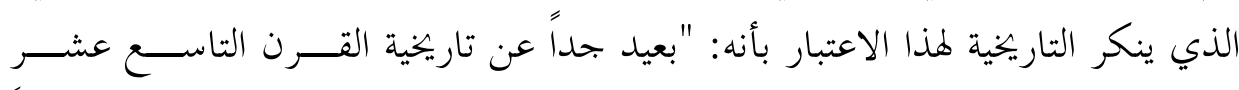

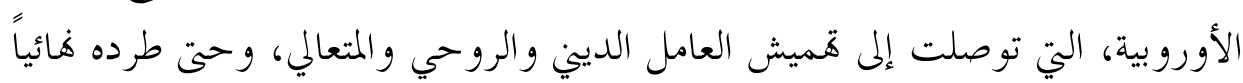

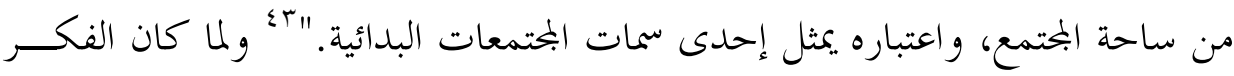

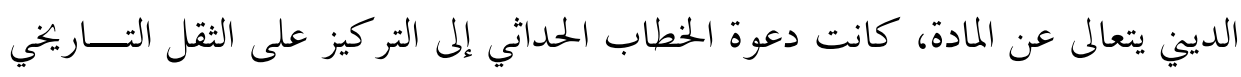

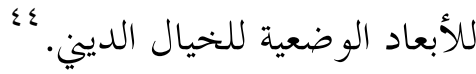
وتتجلى مقولة "التاريخيّة" حسب التوظيف الحداثي في مستويات عدة، أهمها:

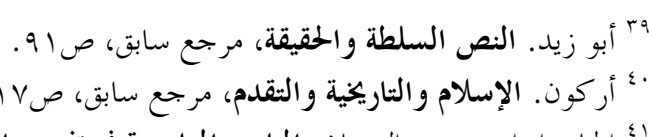

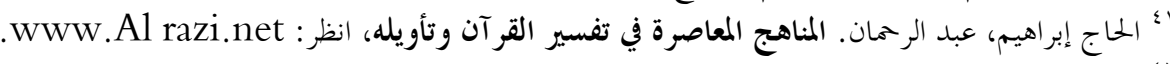

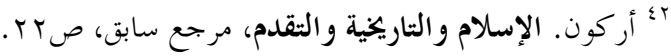

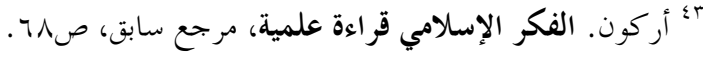

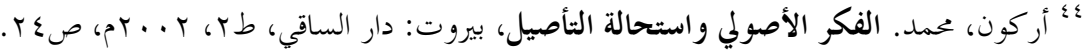




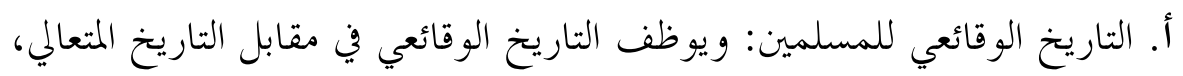

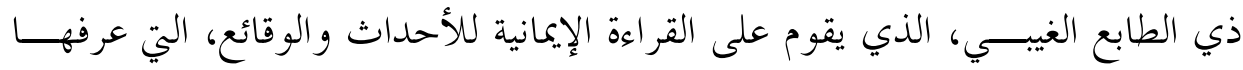

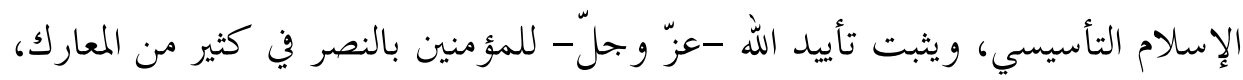

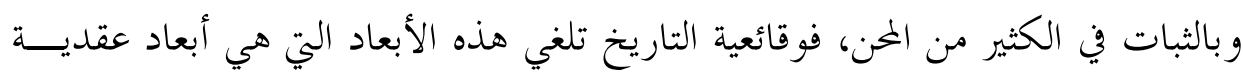

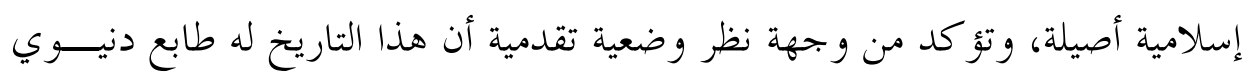

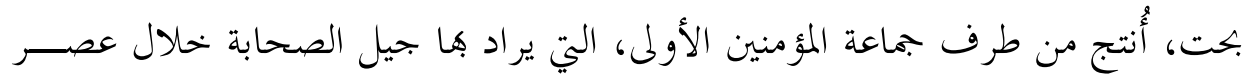
البعثة.

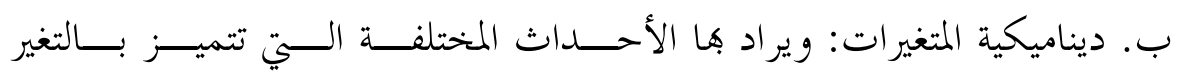

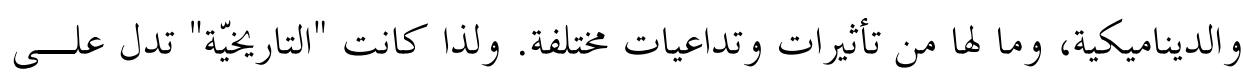

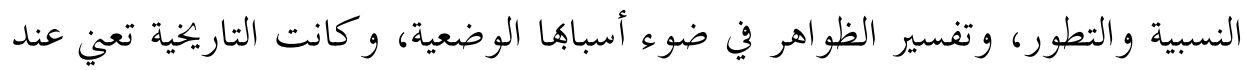

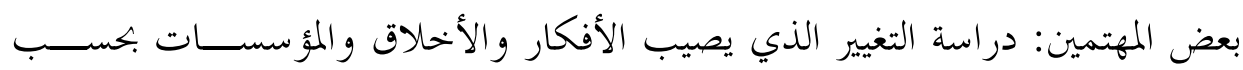

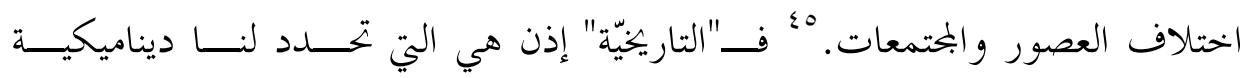

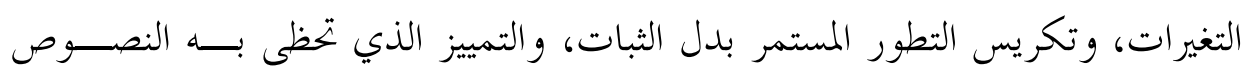

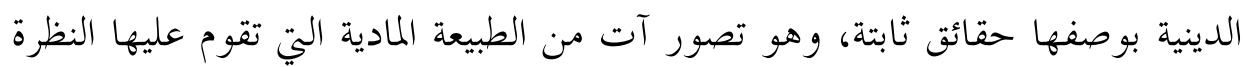
التقدمية، التي ليست نقداً داخلياً، بل هي امتداد للنظرة الوضعية للدين والتئن الأشياء.

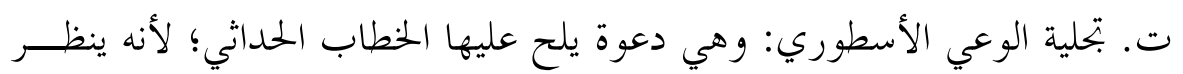

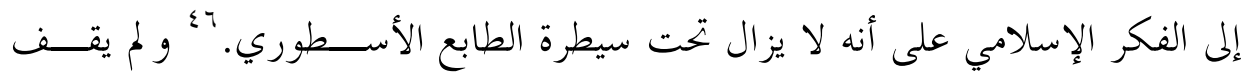

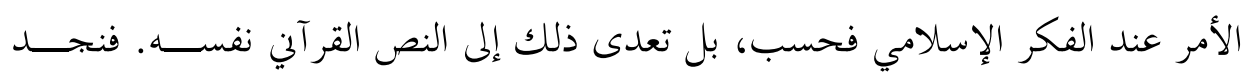

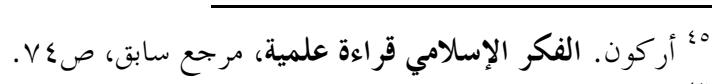

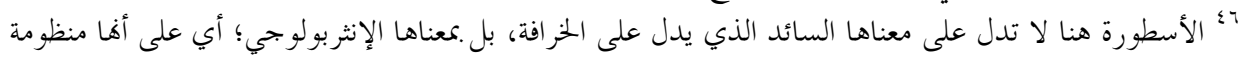

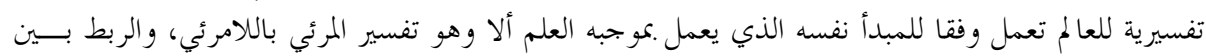

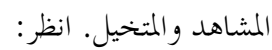

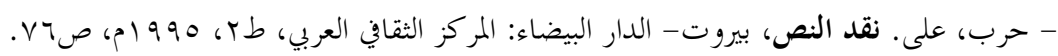

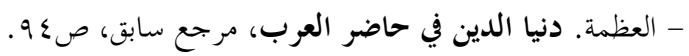

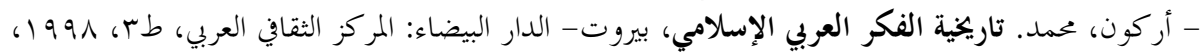




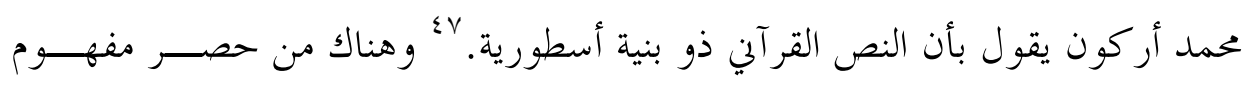

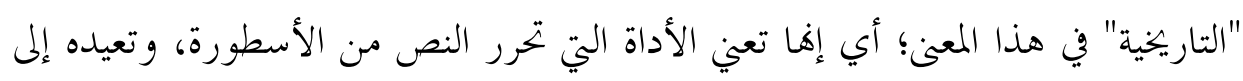

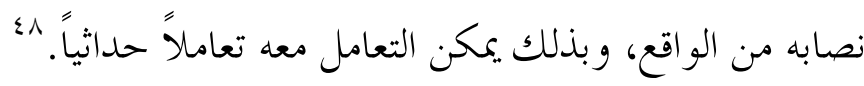

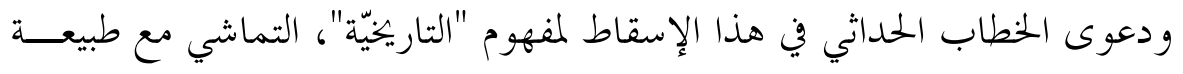

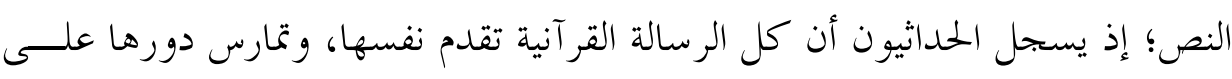

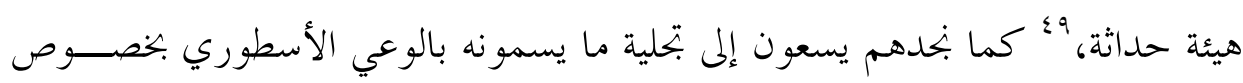

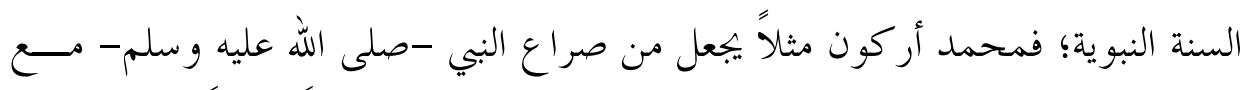

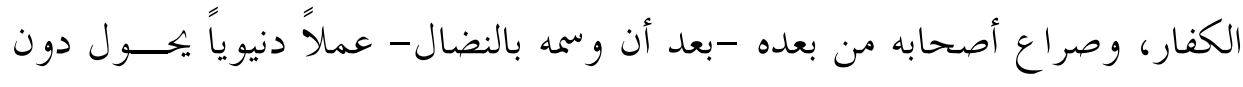

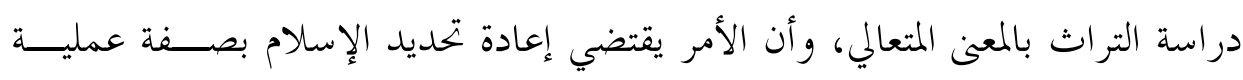

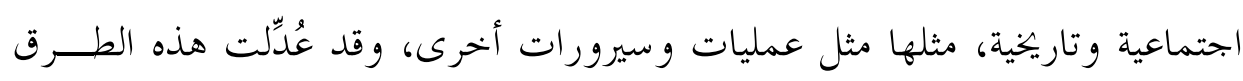
الدراسية عن طريق أشكال الحداثة المتتالية. ،

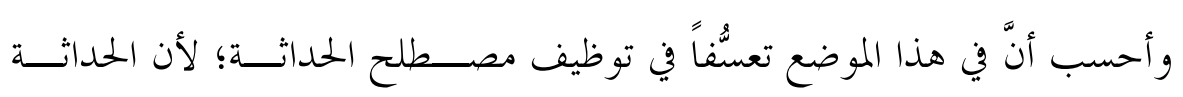

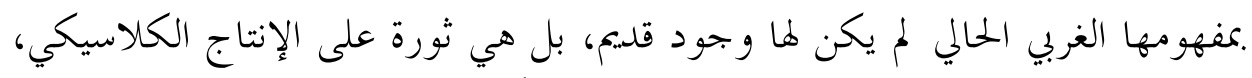

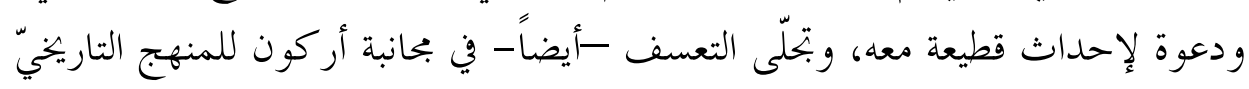

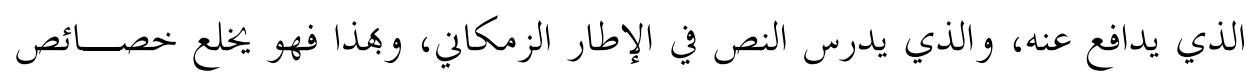
عصر على عصر آخر.

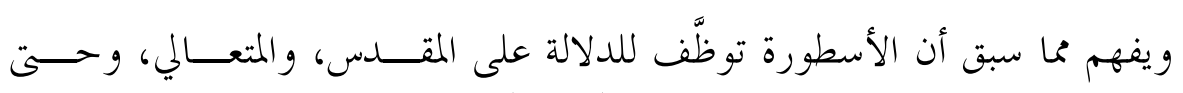

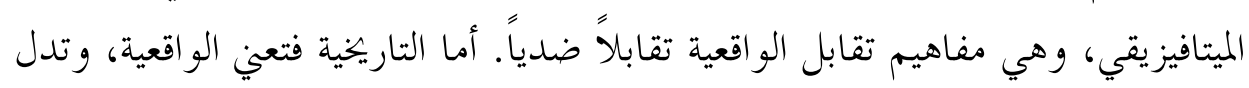

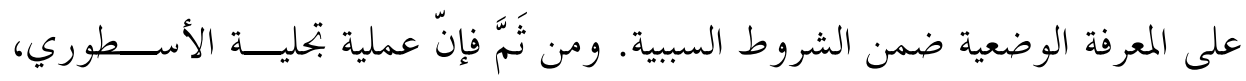

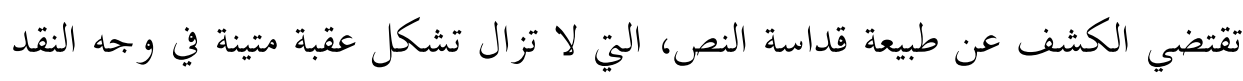

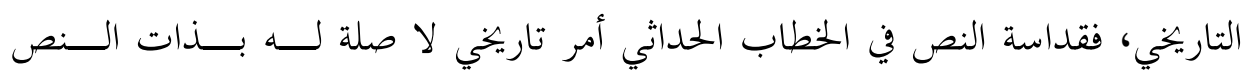

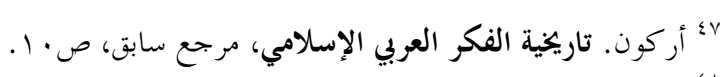

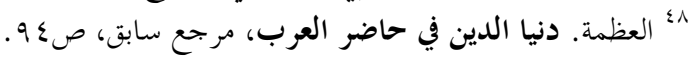

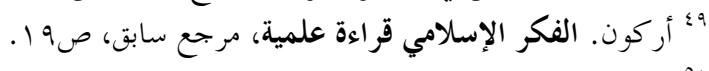
• المرجع السابق، الصفحة نفسها. 


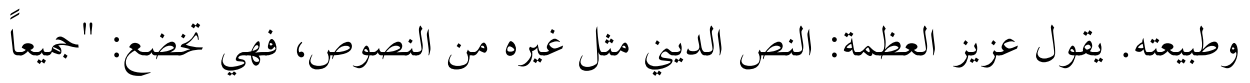

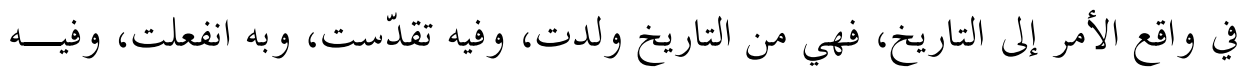

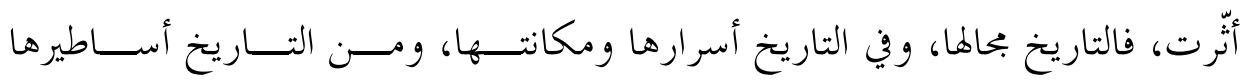

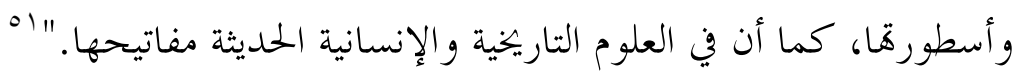

ومن خلال الثقة الممنوحة في العلوم الإنسانية المشار إليها، يمكن بتحلية هذا الوعي

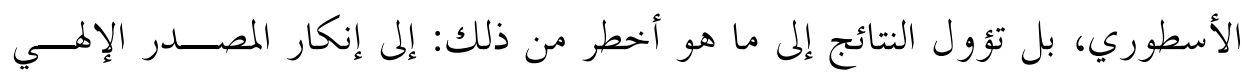

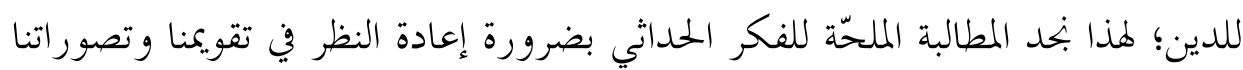

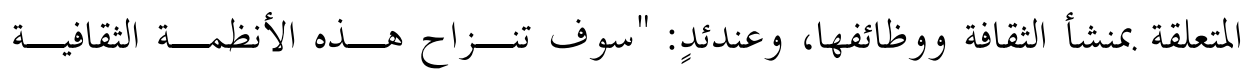

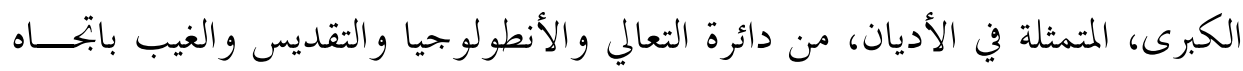

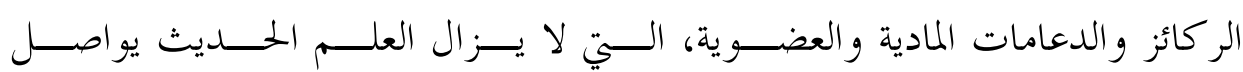
استكشافها." الر وائر والوعات

وبناء على ما سبق نلاحظ أنّ التاريخية بحسب توظيفها الحداثي هدف إلى إثبــاث

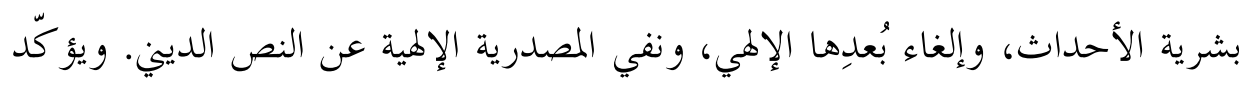

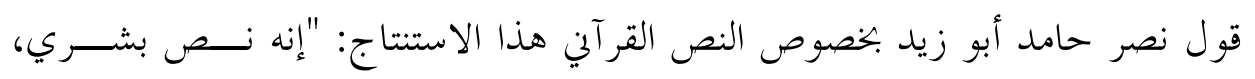

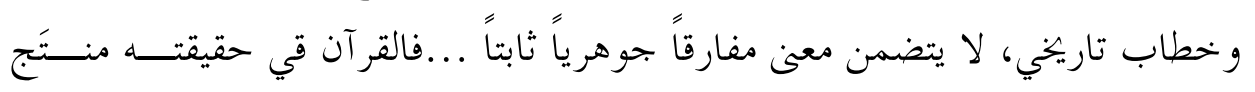

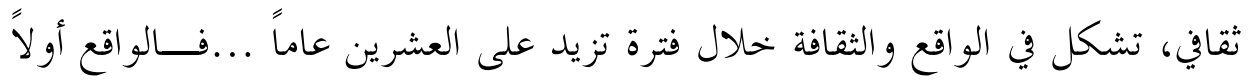

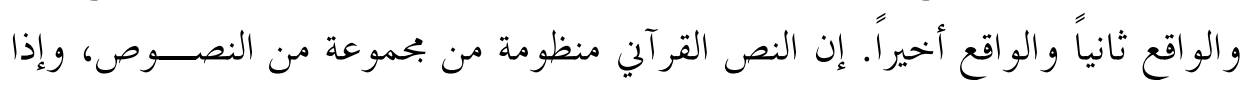

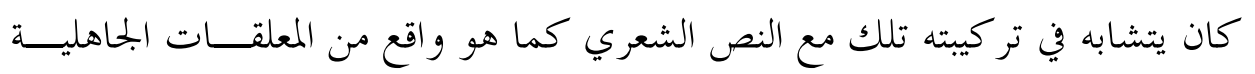

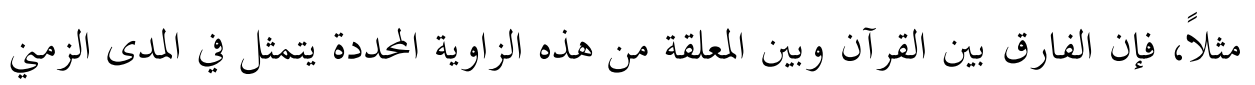

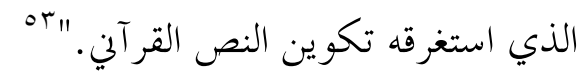

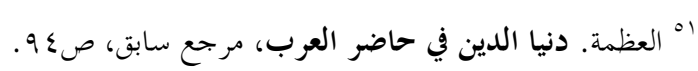

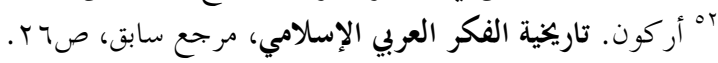

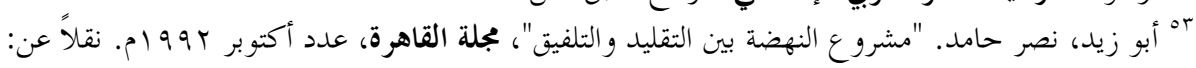

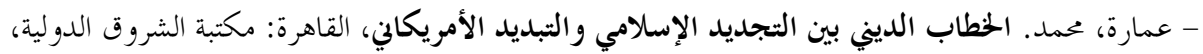
ط 
ب. في مجال دراسة النصوص: وهو بحال حديث، تطور بشكل كبير مع تطـــور

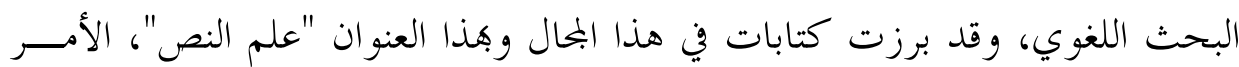

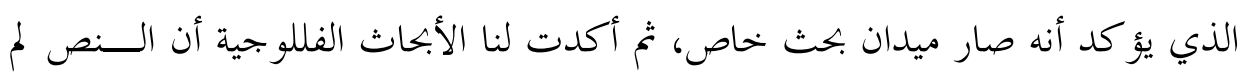

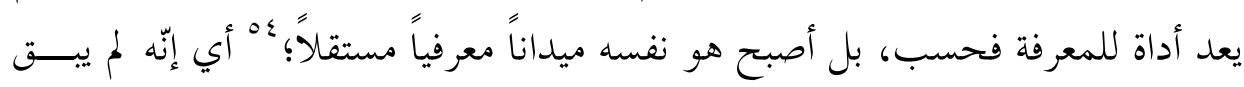

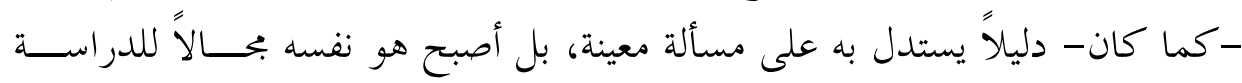

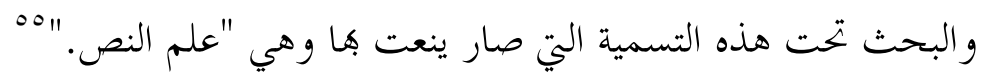

و يلاحظ على الخطاب الحداثي تركيزه على النص الديني، و النظر إلى أنّ طبيعتــه.

القدسية هي التي كانت مفارقة للواقع. وهذا سرّ إبداع هذه الفضاءات المعرفية، بما في

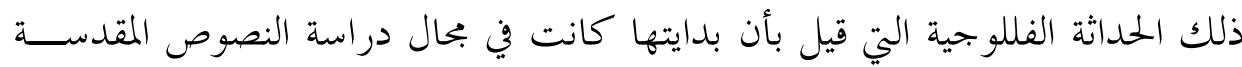

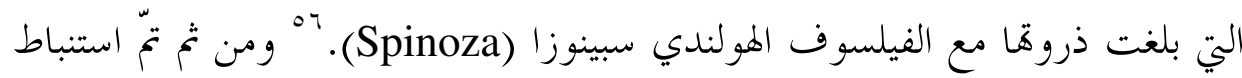

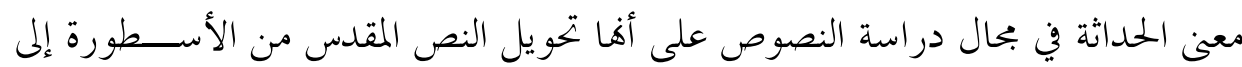

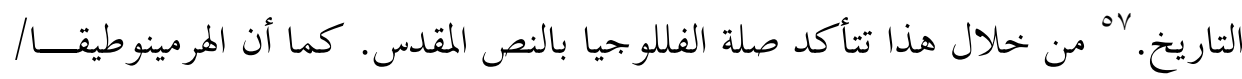

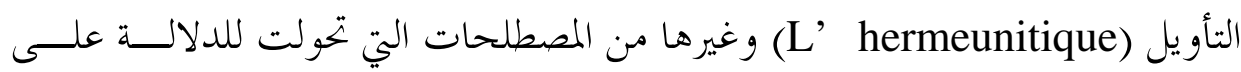

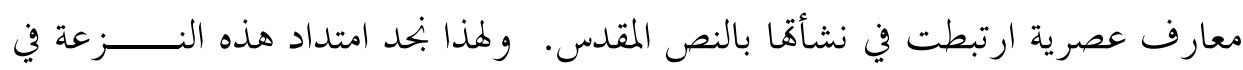
الثقافة العربية الإسلامية؛ فالخطاب الحداثي العربي المعاصر يريد قراءة الـــصـ الــــيني

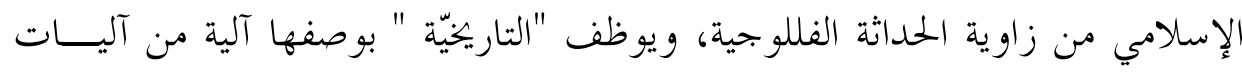

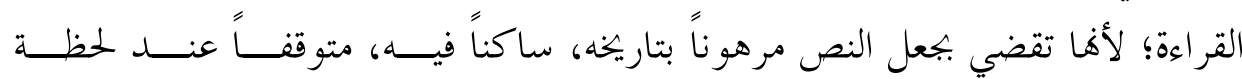

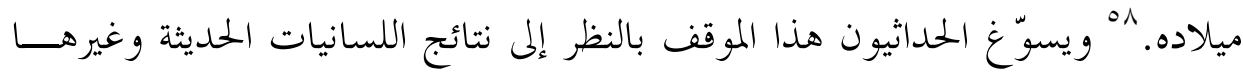

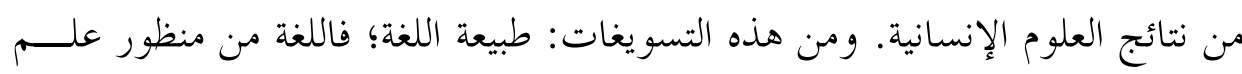

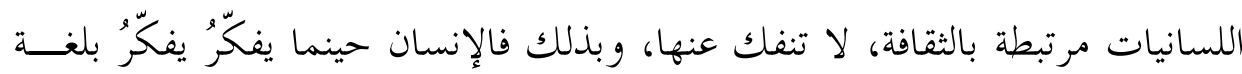

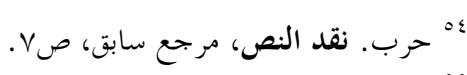

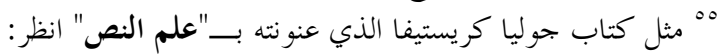

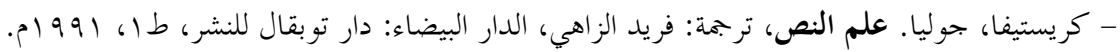

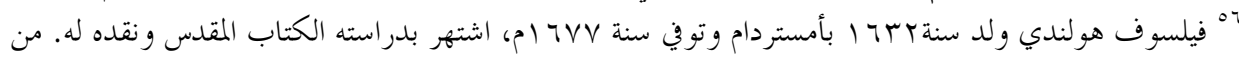
مؤلفاته رسالة في اللاهوت و والسياسة.

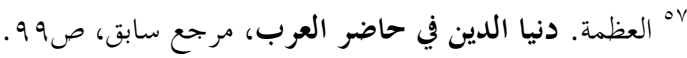

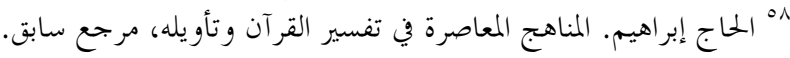




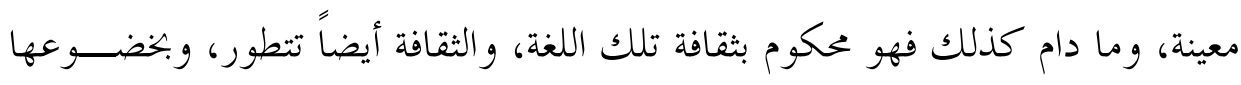

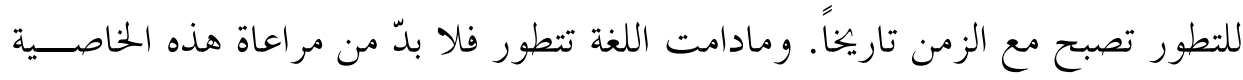

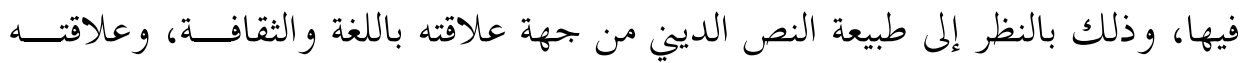

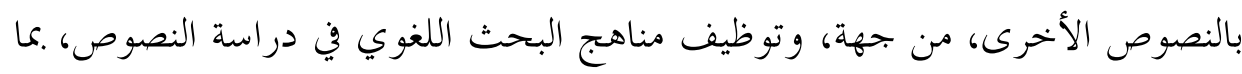
فيها النص الديني، من جهة ثانية.

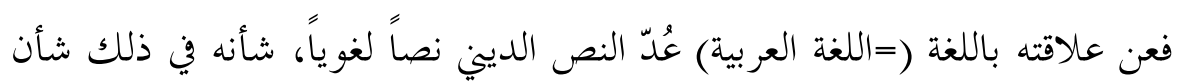

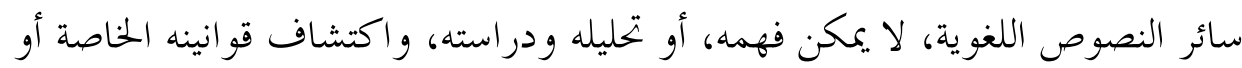

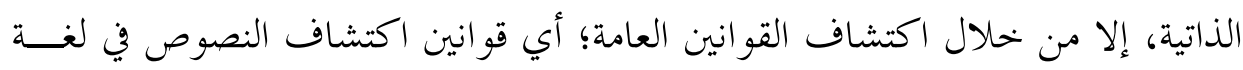
معينة وفي إطار بيئة ثقافية خاصة.

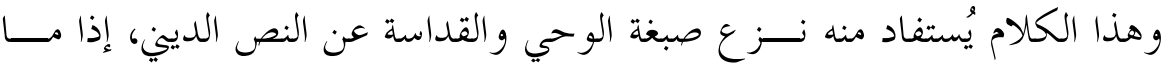

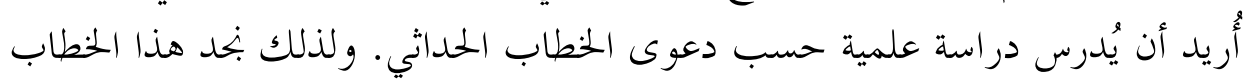

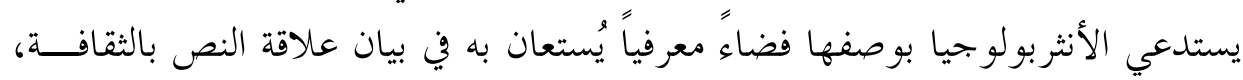

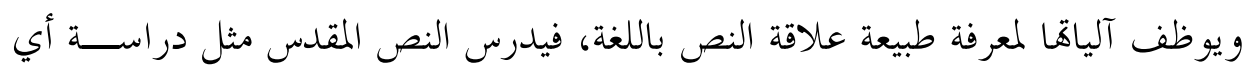

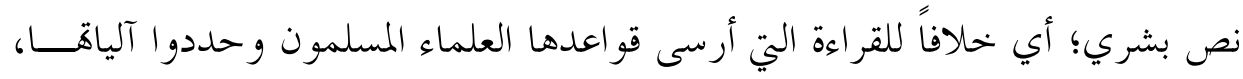

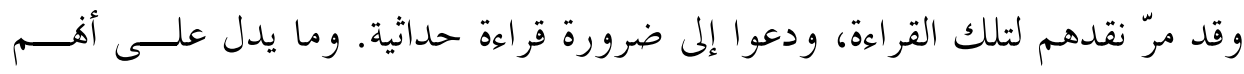

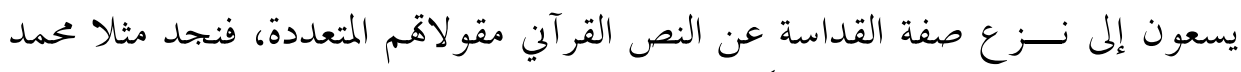

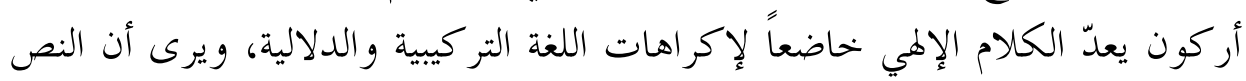

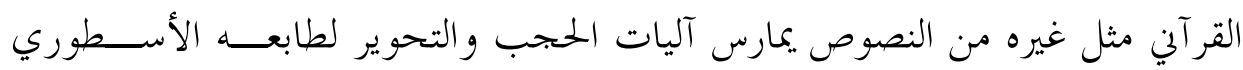

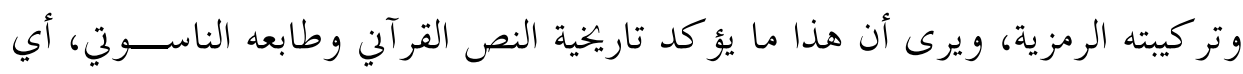

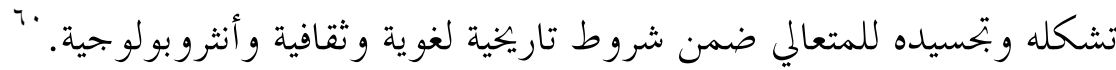

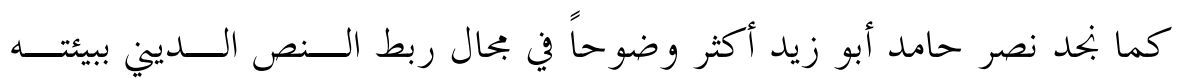

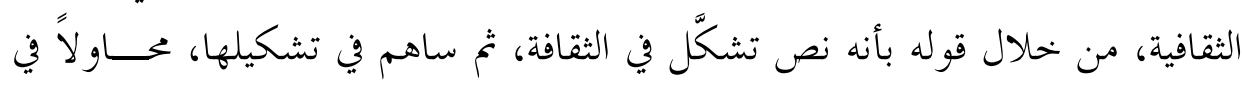

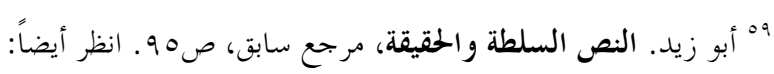

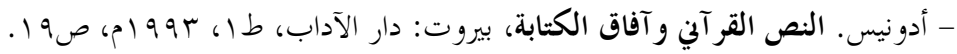

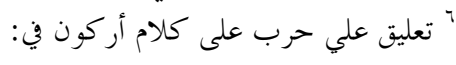

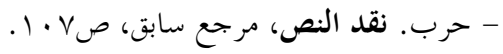


ذلك ربط النص القرآي، والنص النبوي، بالبيئة الاجتماعية وبظواهرهــا، كظهـاهـاهرتي

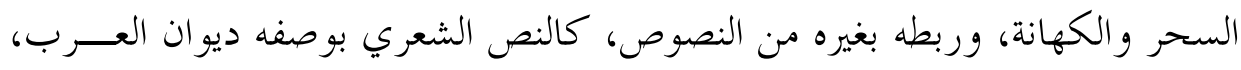

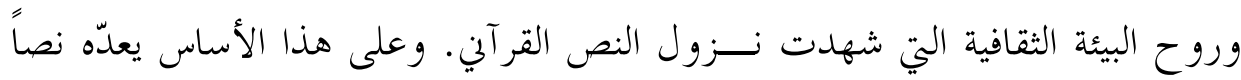

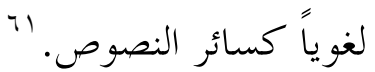

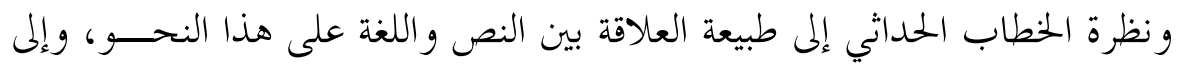

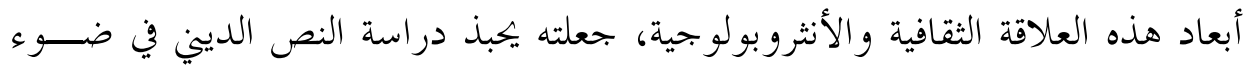

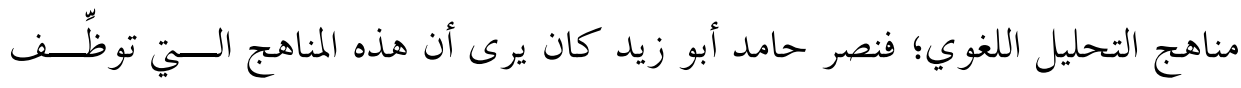

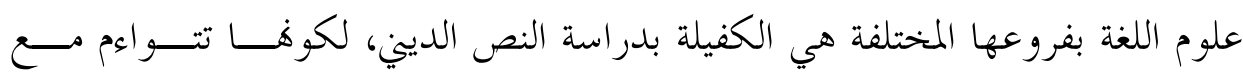

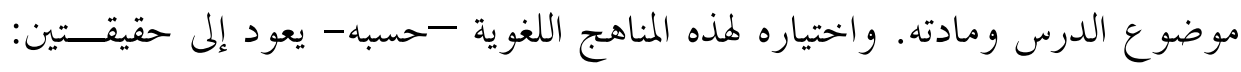

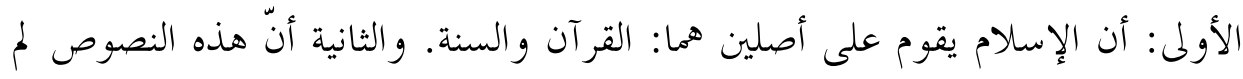

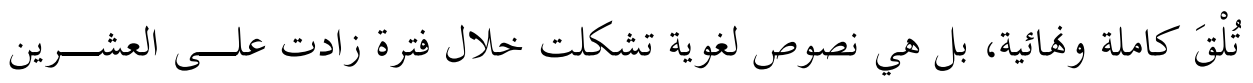
عاماً.

وتركيزه على الحقيقة الثانية يتجلى في دراساته المختلفة، وحاول من خلال هــــه

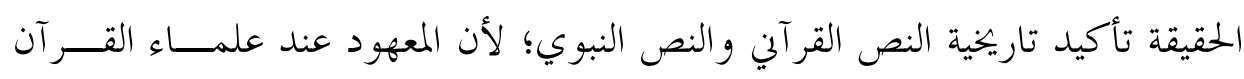

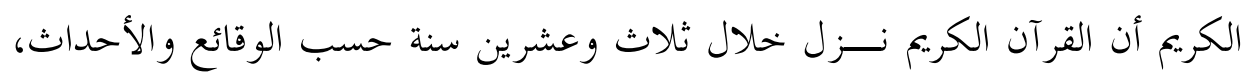

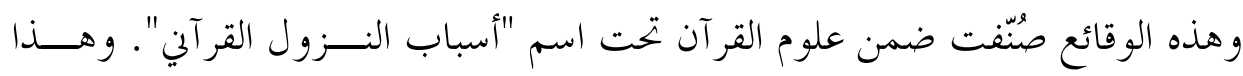

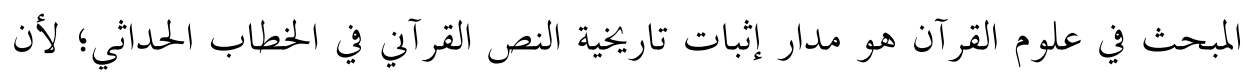

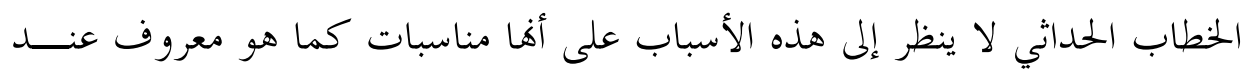

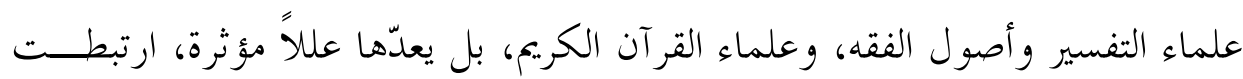

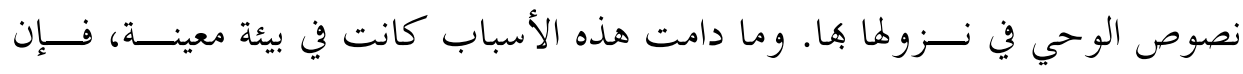
النص مرتبط ببيئته وسببه، ولا يتجاوز في توظيفه ذلك.

"“أبو زيد، نصر حامد. مفهوم النص دراسة في علوم القرآن، بيروت- الدار البيضاء: المركز الثقافي العربي، طه، وماه

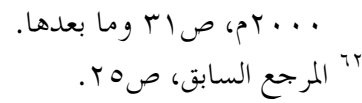


وهذا الأمر أدى إلى هدم مبدأ عموم الدلالة، كما سيتبين ذلك فيما بعد. فمسـن

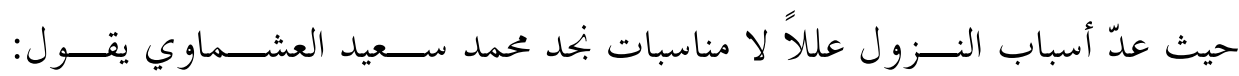

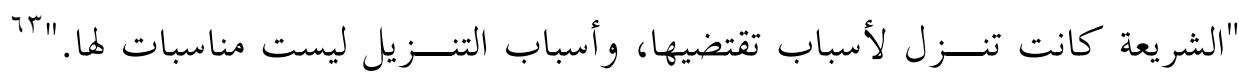

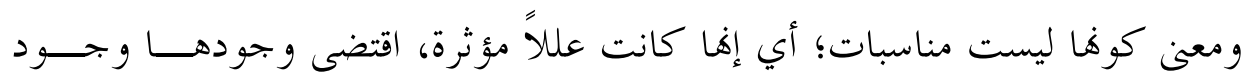

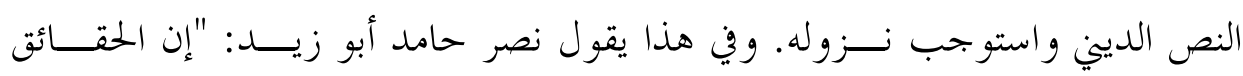

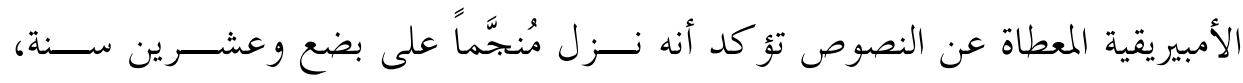

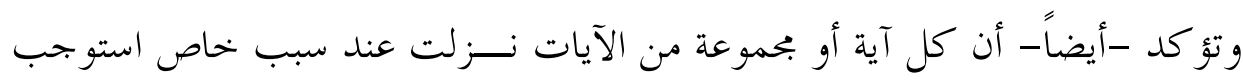

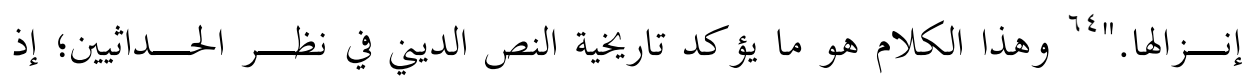

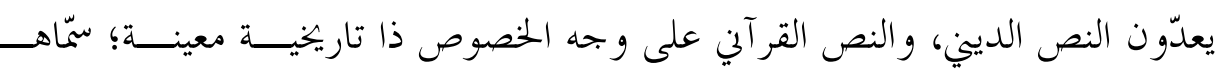

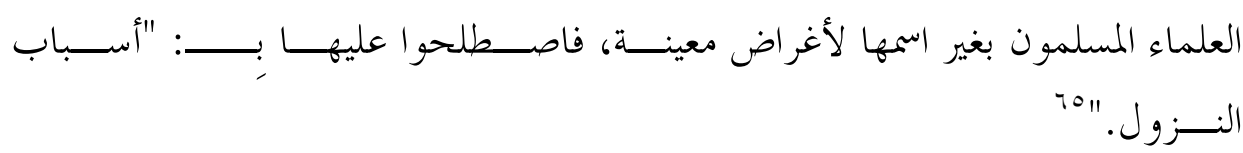

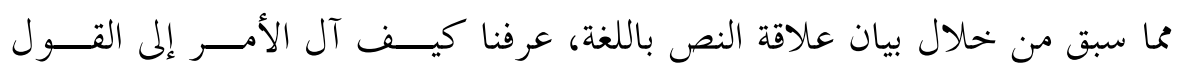

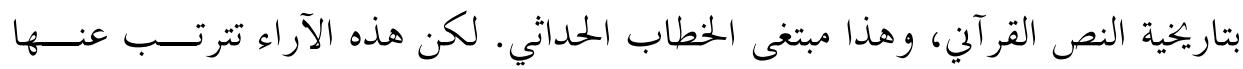

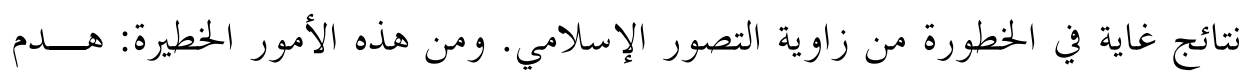

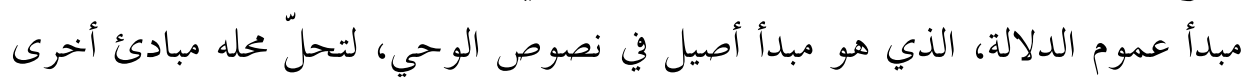

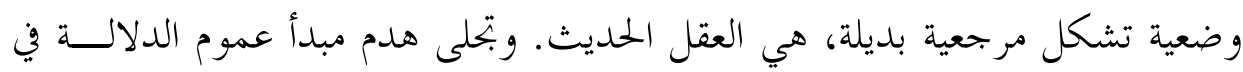
الخطاب الحداثي مع الكثير من الذين ينخرطون في التعاطي مع النص الديني. فنصر حامد أبو زيد يقول: "الأحكام و التشريعات جزء من بنية الواقع الاجتماعي

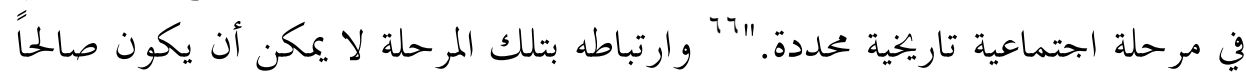

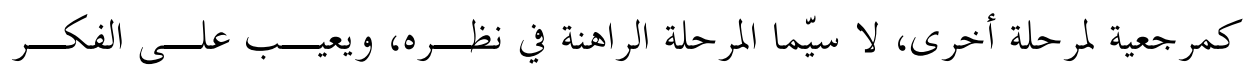

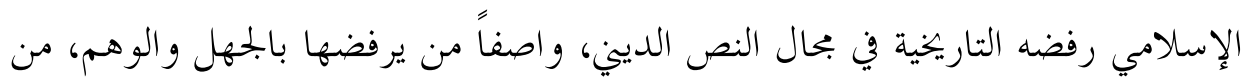

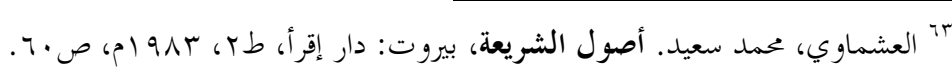

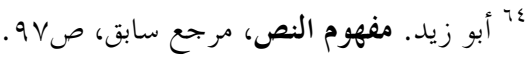

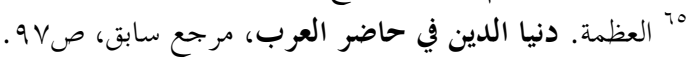

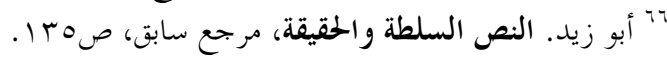


منطلق أن الدلالة اللغوية لها قوانينها التي تختلف عن أنماط الدلالات الأخرى. ويشــير

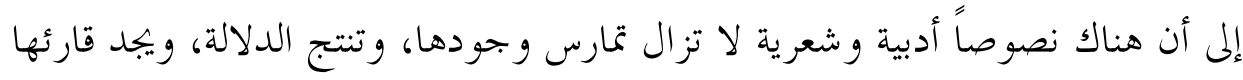

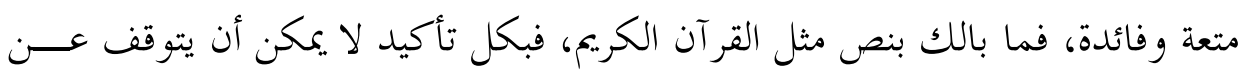
التو اصل دلالياً.

وفي هذا تناقض جليّ؛ فمن جهة يقول بعدم عموم الدلالة، وأن النص مرتبط ببيئة

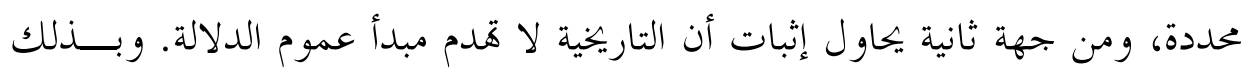

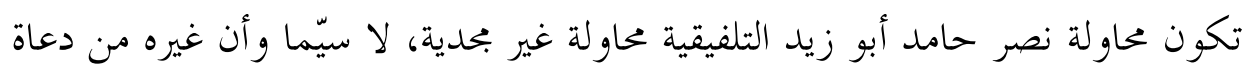

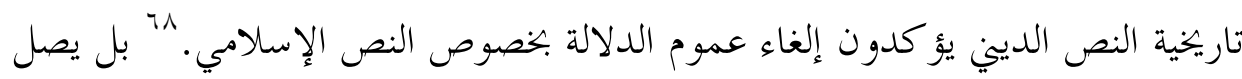
بعضهم إلى قول كلام غاية في الخطورة في إطار دفاعهم عن العلمانية بوصفها رؤيسـة

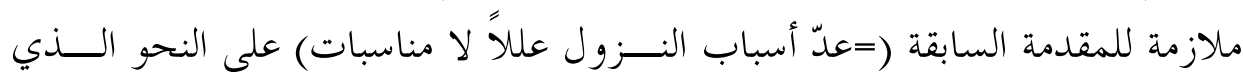

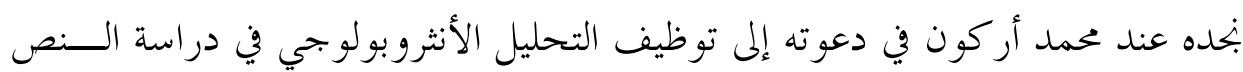

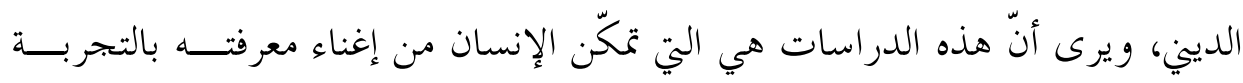

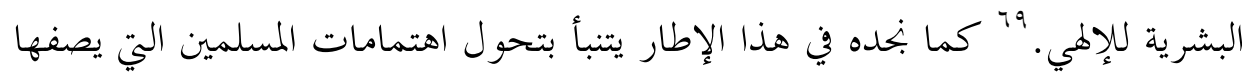

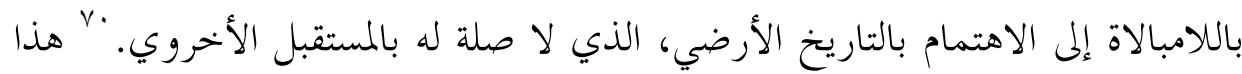

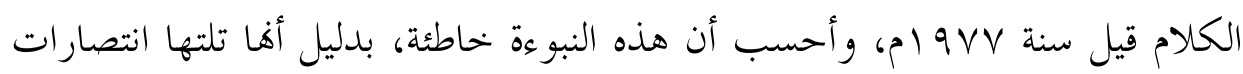
إسلامية عالمية، حقق الفكر الإسلامي فيها تفوقه في أقطار إسلامية عديدة، لعل أقرها

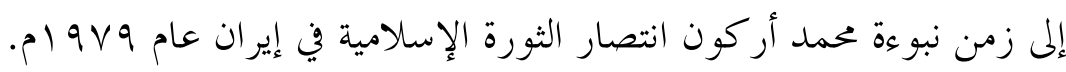

و.ما أنّ مقولة التاريخية وظّفت حداثياً في بحال دراسة النصوص، بما في ذلك النص الديني، فقد عدّ النص الديني مثل غيره من النصوص اللغوية، تُسحب عليه جميع قو انين

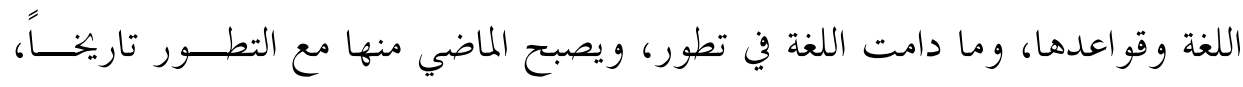

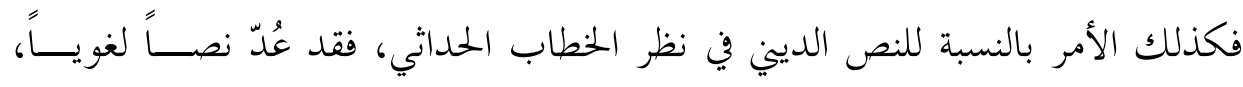

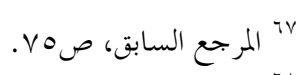

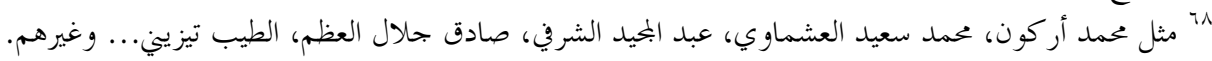

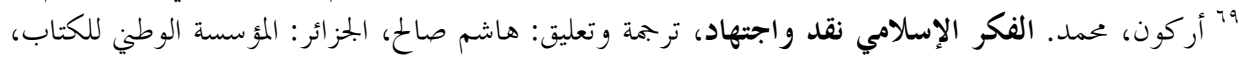


تشكّل في الثقافة، واكتسب سلطته في الواقع، وأُضْفيت عليه القداسة، و لمُ يكن مقدساً

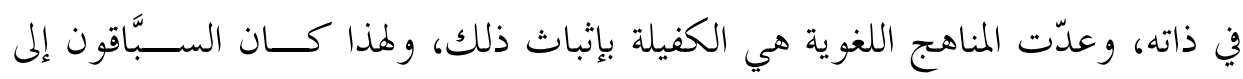
طرق هذه المو اضيع هم علماء اللغة. ويخص الخطاب الحمداثي بالذكر هنا طه حســين،

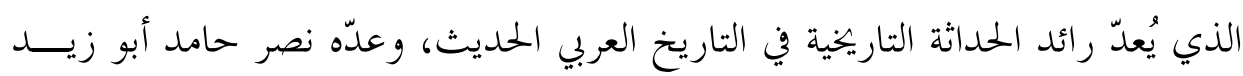

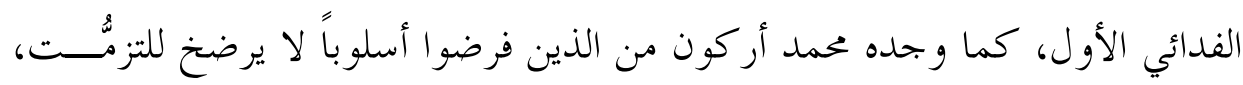

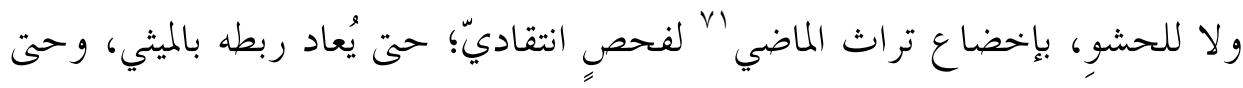
يتم فضح التمويه، و إعادة الآفاق التاريخية الصحيحة.

أمام هذه التوظيفات الحماثية المختخلفة لــلـالتاريخيّة"، وأمام وقوفنا على الأهـــــاف التي كانت ترمي إليها تلك التوظيفات؛ فقد كان توظيفها في نقد القراءة السائدة بغية

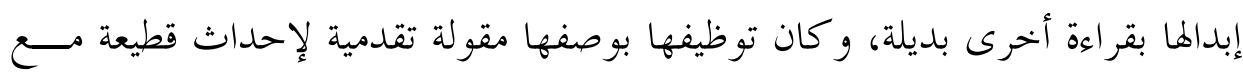

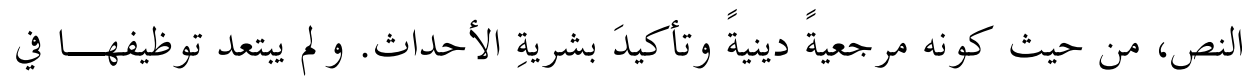

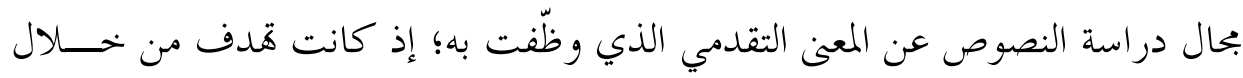

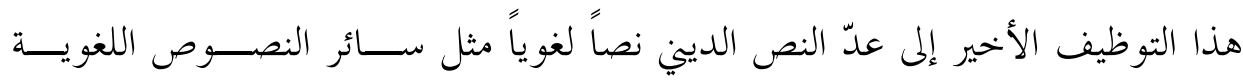
البشرية.

ولا شكّ في أنّ هذه التوظيفات الحداثية لمفهوم "التاريخيّة" في بحال دراسة الـــصص

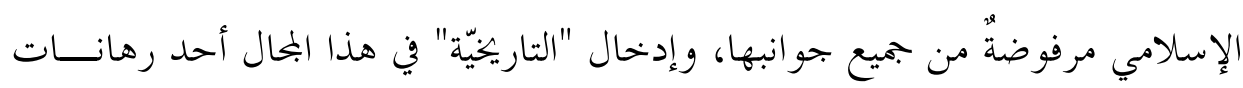

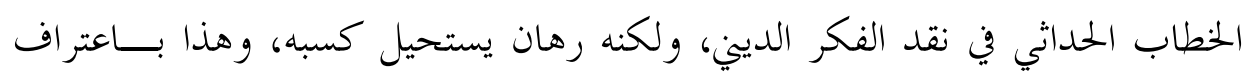

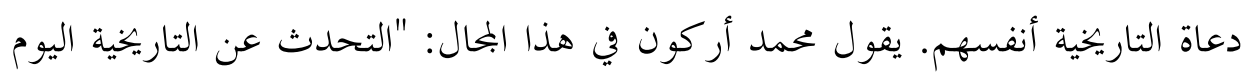
بصورة منطقية في الوسط الإسلامي أمر ضروري من وجهة نظر ذاتية (=وجهة نظـــر

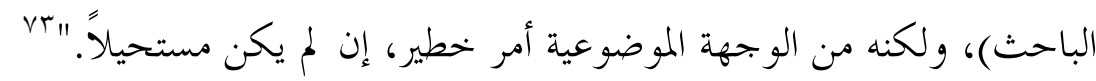
" يو طف محمد أركون مصطلح التراث لا للدلالة على التراث بالمعنى السائد فقط، بل للدلالة على نصوص الوحي

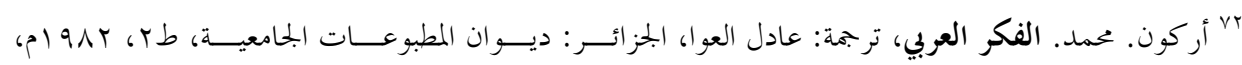
"rr أركون. الإسلام والتاريخية والتقدم، مرجع سابق، ص آ. 
وو جه الاستحالة هنا في كون التاريخية تلامس مناطق محرمة، وتطرق أبواباً بشكل

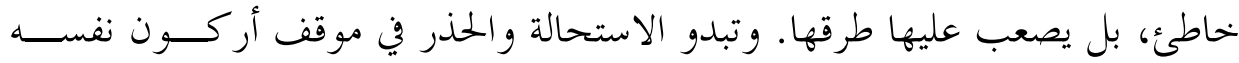

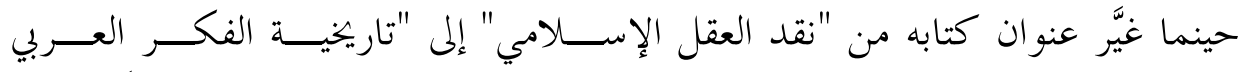

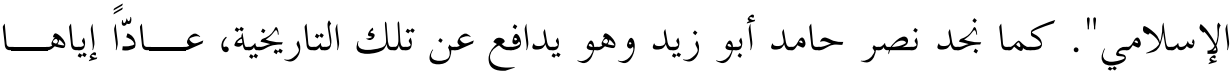

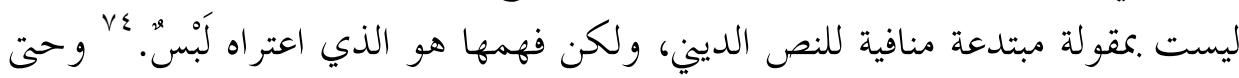

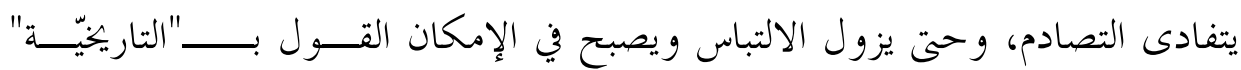

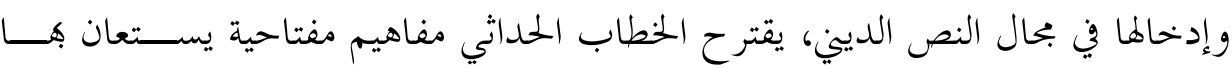

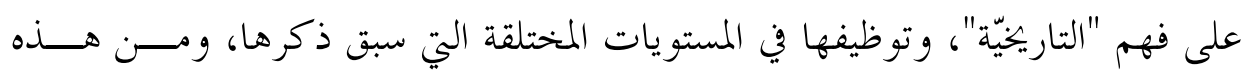

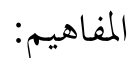

- الدوغمائية: (Le dogmatisme) أو الوثوقية، وهي من المفاهيم الإجرائيــة

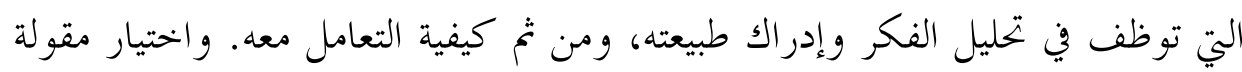

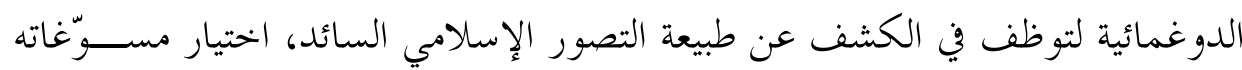

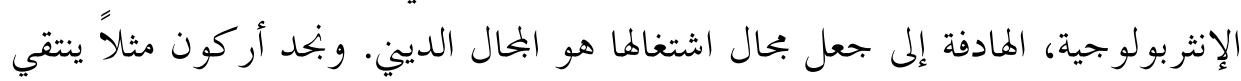

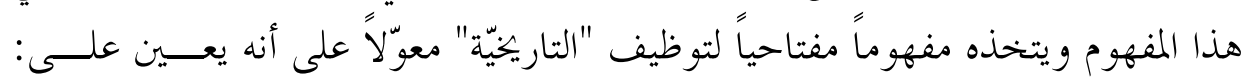

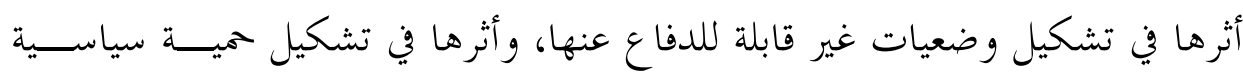
و دينية، و كيف تحولت إلى استر اتيجية رفض.

ومن خلال هذه الوظائف المنوطة بـــالدوغمائية" بوصفها مفهوماً مفتاحياً، يمكن

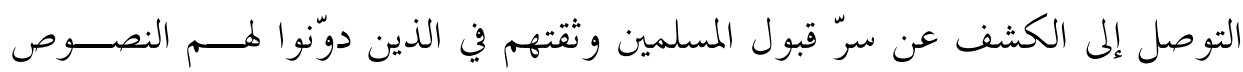

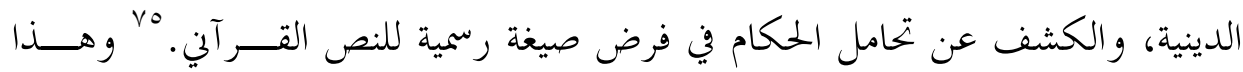

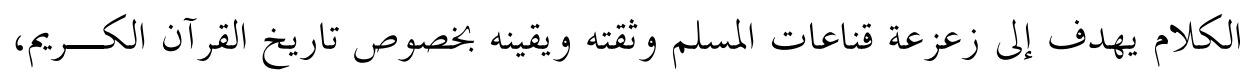

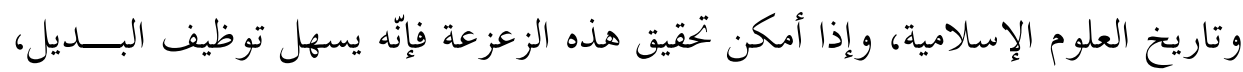
الذي هو العلمانية.

- الانتقال من الفكر الميثي إلى الفكر التاريخي الوضعي: والميثي نسبة إلى كلمة

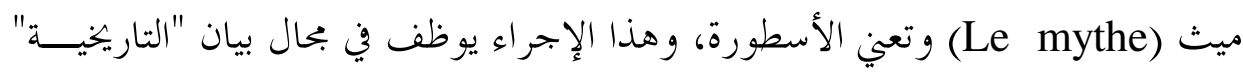

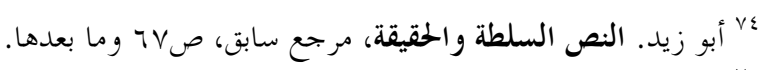

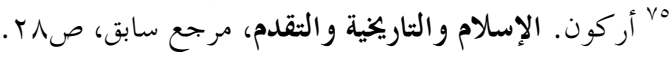


بوصفها مقولة تقدمية، تؤيدها نتائج العلوم المعاصرة، والعقل الوضعي. وحتى يتسـئن

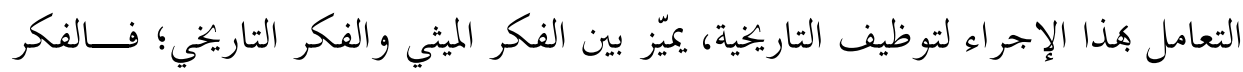

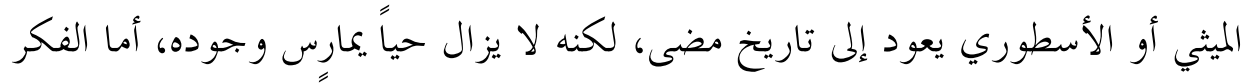

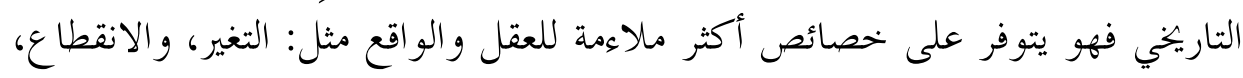

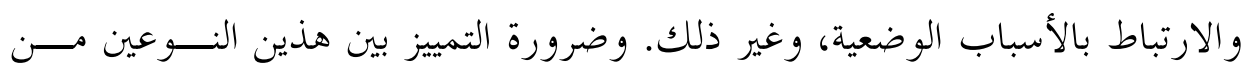

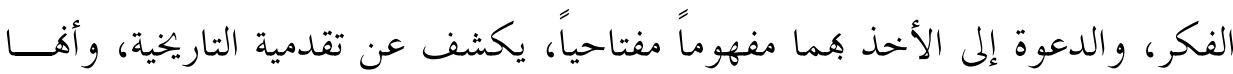

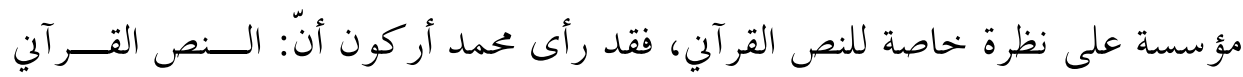

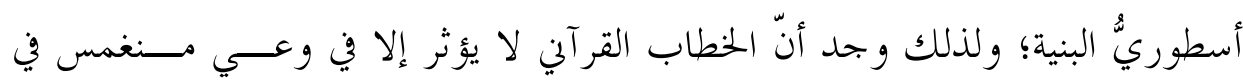

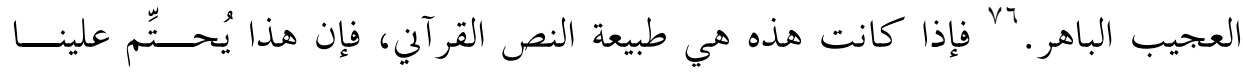

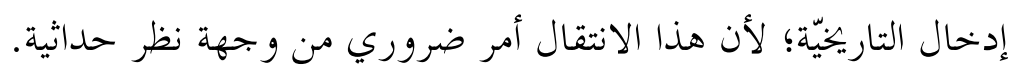

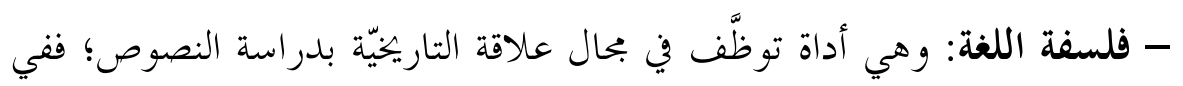

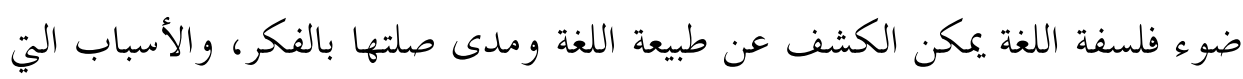

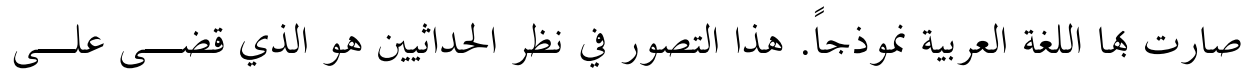

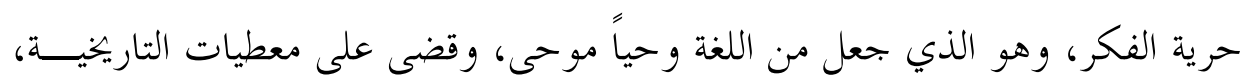

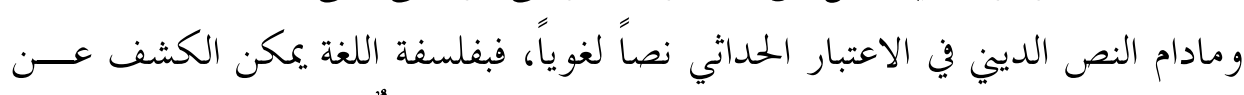

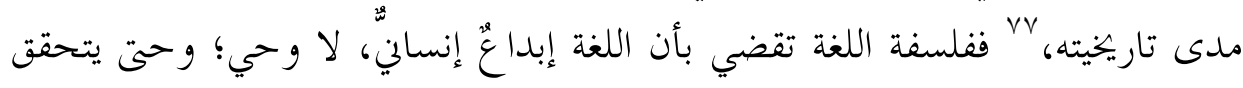

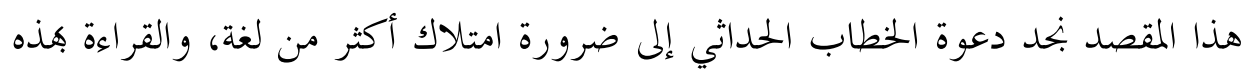

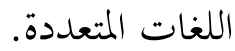

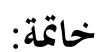

من خلال عرضنا لهذين البعدين للتاريخية: مفهومها الذي تم التطرق إليه من جهة

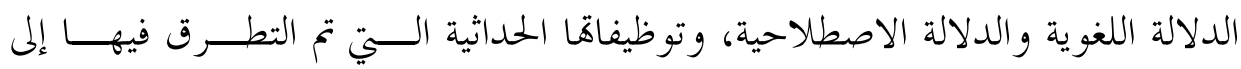

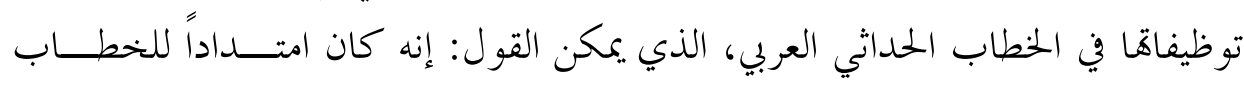

$$
\begin{aligned}
& \text { TrV المرجع السابق، صو r . }
\end{aligned}
$$

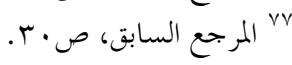


الغربي في الإطار العربي الإسلامي، وإلى أهم الآليات التي يتوسل ها في عملية الأرخنة، يمكن تقرير النتائج الآتية:

- التاريخية بما هي مفهوم، تم إبداعه في الفضاء الفلسفي الغربي، وهو على ارتباط

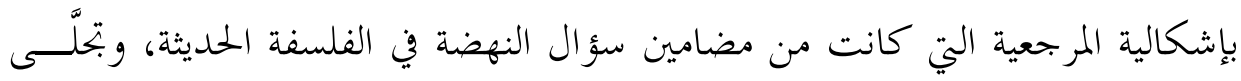
توظيفها في الصراع الذي كان دائراً بين الفكر الديني والفكر الوضعي في الغربئ الغران. - التاريخية مفهوم يُكرِّ القطيعة مع الماضي، ويعدّ المواقف والمسائل و النصــوص

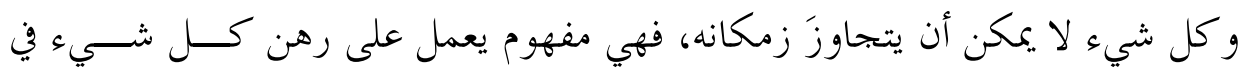
تاريخه. وهذه القطيعة المكرسة صارت لها بتحليات مختلفة، منها الانتقال من المقصـــــية إلى موت الكاتب بو صفه إجر اء هرمينوطيقياً.

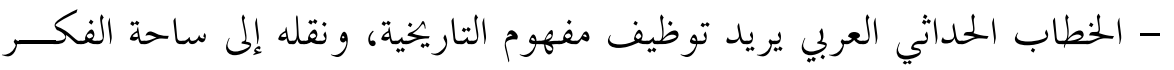

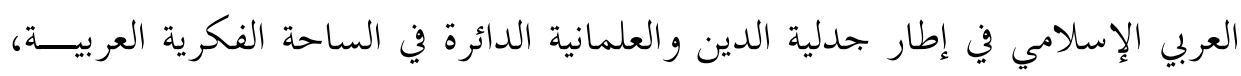

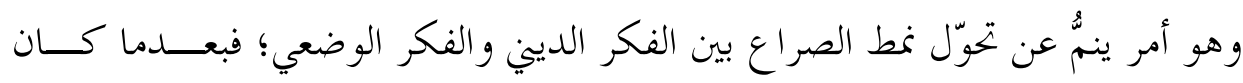
الرافض للمرجعية الدينية يتموقع خارج النص صار يتموقع داخل النص، وبعدما كان الرفض يبدأ من خارج النص صار يبدأ من النص ذاته، وبعدما كانت آليات الـــرفض العلوم الطبيعية، صارت العلوم الإنسانية. - مفهوم التاريخية على ارتباط .مسألة القراءة؛ ولذلك يوظف بكيفيتين:

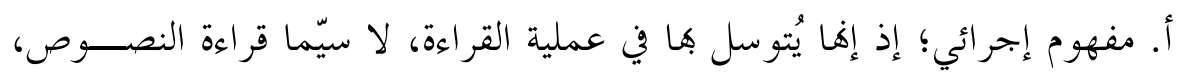

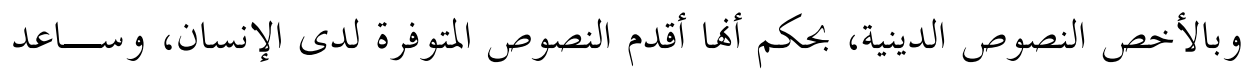

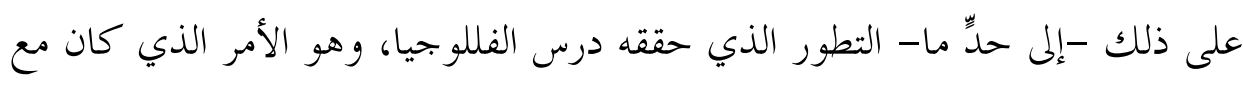
قراءات (سبينوزا) في بدايات عملية التحديث، وي الفلسفة المعاصرة مــع (غاســتون

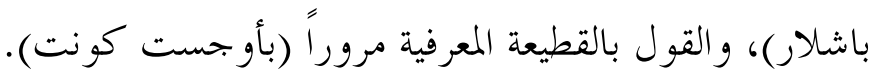


ب. مذهب ورؤية: توظّف التاريخية بوصفها مذهباً يسلكه المؤمنون به، ليؤسسوا من خلاله رؤى و أحكاماً على المو اقف و النصوص ورو المسائل. - توظيفات الحداثيين للتاريخية إجراء ورؤية" في الإطار الإسالمي انبنى على عملية المقارنة، وهي مقارنة ليست صحيحة من جميع و جوهها؛ لأن القول بتاريخيــة الـــص الديني الإسلامي يفضي إلى نتائج تخالف الإسلام ذاته، مثل التشـــكيك في مصـــــرهـ

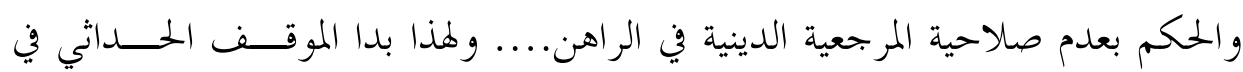
القول بتاريخية النص الإسلامي مضطرباً، كما تم بيان ذلك من مقو لات نصر حامد أبو زيل و وحمد أركون. 